\title{
Legal Imagination in Vitoria. The Power of Ideas
}

\author{
Pablo Zapatero*
}

Professor of Public International Law, Carlos III University, Madrid, Spain

\section{A Man's Ideas}

Legal progress is often propelled by concepts first envisioned in academia. In this light, the present article explores the ideas of a fascinating intellectual figure: Francisco de Vitoria (I483-I546), ${ }^{\mathrm{I}}$ a man broadly recognized as one of the "founding fathers" of international law. The writings and lectures of this I6th century Dominican friar formulated innovative legal doctrines in an age of uncertainty and profound social change; an age that gave birth to the modern States that, with their centralized power, signalled the demise of medieval pluralism, the dismemberment of Christendom, and the erosion of imperial and papal aspirations to universal power.

Medieval Europe, before then, had defined itself as a cultural, political and religious unity: the Res Publica Christiana. The first half of the I6th century witnessed the final breakdown of that order, the emergence of the modern sovereign state and the subsequent development of the European state system. It was also in this age that a singular event transformed conventional conceptions of the world and consolidated anthropocentrism: the discovery of America. ${ }^{2}$ A 'stellar moment' of literature, political and legal

\footnotetext{
* For correspondence use pablo.zapatero@uc3m.es. Unless otherwise indicated, translations in this paper are by the author.

I) See Getino, L.G. El Maestro Fr. Francisco de Vitoria: Su vida, su doctrina e influencia, Imprenta Católica, 1930 and de Heredia, Beltrán. Francisco de Vitoria, Editorial Labor, 1939. 2) Pérez Luño, A. La polémica sobre el Nuevo Mundo. Los clásicos españoles de la Filosofía del Derecho, 1992, p. I7.
} 
thought took place in the Iberian Peninsula: the golden age of Spain. One of the most innovative intellectual movements of that period, the so-called School of Salamanca, was formed under that aegis. ${ }^{3}$ This Doctrinal movement sparked a profound renewal of Spanish Scholastic thought. ${ }^{4}$

Francisco de Vitoria, Domingo de Soto and Francisco Suarez are the foremost representatives of this Seconda Scolastica. Their collective effort produced, in essence, a "revamped Scholasticism", different from that of the early Middle Ages which evokes, to paraphrase Truyol, a preoccupation with trivial distinctions, classifications and the "inflation of abstraction" at the expense of reality. ${ }^{5}$ To the contrary, Vitoria and his colleagues developed and disseminated new ideas by guiding and nurturing this academic current with a characteristically direct concern and contact with the issues of the time. ${ }^{6}$

Three basic dimensions are interrelated in the work of Francisco de Vitoria: theology, political power, and the Law of Peoples. To summarize, he adopted a stance typical of classical Natural Law theorists, ${ }^{7}$ addressing the major issues of his time by reconciling philosophy and theology on the basis of Christian morality and Natural Law. His ideas are rooted in Thomist and Nominalist doctrines, and exude Catholic influence. Vitoria maintained that there was no contention, issue or dispute that did not fall within the bounds of Theology. ${ }^{8}$ This broad conception of theology allowed him to examine a wide range of social issues, which he approached with independent criteria and a critical sense. For this reason, he has occasionally been described as a "theologian confronting power."' Some of his key

3) For the manuscripts of 2I theologians from this group see Ehrle, F. Los manuscritos vaticanos de los teólogos salmantinos del Siglo XVI, Biblioteca de Estudios Eclesiásticos, I930.

4) Truyol, A. "Vitoria et la tradition scolastique", Aspects de la pensée médiévale dans la philosophie politique moderne, Edition by Y.Ch. Zarka, Paris, 1999, pp. 70-82.

5) Truyol, A. "Vitoria et la tradition scolastique" ... op. cit. pp. 70-7I.

6) See Hamilton, B. Political Thought in Sixteenth-Century Spain: A Study of the Political Ideas of Vitoria, De Soto, Suárez, and Molina, Oxford, 1963.

7) Pérez Luño, A. La polémica ... op. cit.

8) Vitoria, F. "De potestate civili", Obras de Francisco de Vitoria. Relecciones Teológicas, annotated edition by Teófilo Urdanoz, Madrid, I960, p. I50. See Langella Sichenz, S. "Apuntes sobre el concepto de teología en Francisco de Vitoria, 30 Cuadernos salmantinos de filosofía (2003): 277-290.

9) Carrillo Salcedo, J.A. "Aportaciones de Francisco de Vitoria a los fundamentos filosóficos de los derechos humanos", La Escuela de Salamanca y el Derecho Internacional en América. 
theses bear witness to that relation. In fact, his ideas drew the attention of Charles V himself, who was deeply displeased that doctrines contrary to his interests were being taught at the University of Salamanca.

Francisco de Vitoria is recognized today as one of the main intellectual founders of international law, along with later thinkers such as Alberico Gentili (I552-1608) and Hugo Grotius (1583-1645). ${ }^{\text {I0 }}$ However, when modern academic literature began to pay attention to this subject, the credit was originally given solely to Grotius, although he himself used the words of the blackfriar (Vitoria) extensively to develop his famous legal brief for the Dutch East India Company; and these ideas would later figure in his anonymously published Mare Liberum. Nonetheless, at the beginning of I9th century, Vitoria was mentioned only for his contributions to the renewal of Scholasticism. Academic interest reawakened with Mackintosh's "rediscovery" of the universalist aspect of his work in I8I6. Later, the issue was addressed in works by Alvarez de los Corrales (I859), Ernest Nys (I894), Barthelemy (1904), J. Brown Scott (1928) and other scholars. ${ }^{\text {II }}$

However, Scott is the scholar who has had the greatest influence in citing the importance of the blackfriar to the development of the discipline of international law. In his words: "Francisco de Vitoria [...] has long been known as a theologian, a moralist, and a humanist; today his reputation is that of a jurist and philosopher as well; tomorrow it will be that of an internationalist and a humanitarian; and many believe that he is destined to be regarded as the founder of the modern Law of Nations." "I2 In any case, the "battle over the founders of international law", using Peter Haggenmacher's expression, ${ }^{13}$ is still being fought today in many forms and for many reasons. But first, let us briefly focus on the intellectual figure of the man.

Vitoria was a highly recognized professor, yet he never committed a text to print. He certainly had every opportunity to publish and in fact

Del pasado al futuro. (Araceli Mangas Martín, Ed.), Salamanca, I993, p. 52.

г) Truyol, A. "Grotius dans ses rapports ave les classiques espagnols du droit des gens", I82 Recueil des Cours (1984): 43I-45I.

II) For a fine study on this process see Haggenmacher, P. "La place de Francisco de Vitoria parmi les fondateurs du droit International", Actualité de la pensée juridique de Francisco de Vitoria, Bruylant, 1998, p. 27-36.

I2) Scott, J. Brown The Spanish Origins of International Law: Francisco de Vitoria and his Law of Nations, 1934, p. 68.

13) Haggenmacher, P. "La place de Francisco de Vitoria ... op. cit. p. 35. 
advocated for the purchase of one of the first university presses in Spain. The reason for his lack of publication was perhaps not that he was focused more on teaching but rather that his new ideas would be better served in the minds of his students, pupils and disciples than exposed in published texts subject to the surgery of expurgation. Fortunately, some of his reflections have been preserved in his manuscripts and some through verbatim notes taken in class by his students. This confirms that Vitoria's intellectual creations were directly linked to his teaching activities, and are therefore found in the texts prepared for his classes (Lectios) and in the traditional end-of-term special lectures (Relectios) presented to the whole university community at Salamanca.

These texts, together with his Commentary on the Summa Theologiae of Thomas Aquinas, give an accurate intellectual portrait of the man; but the most distilled expression of that intellectual activity is clearly found in the Relectios. Of these, three are especially relevant to the history of ideas: De potestate civili (On Civil Power, I528), De Indis recenter investis (On the Indians Recently Discovered, 1539) and De Indis sive de Iure Belli hispanorum in Barbaros (On the Indians, or on the Law of War made by Spanish on the Barbarians, I539). These conferences constitute one of the most far-reaching positions taken in that age concerning political power and relations amongst peoples. ${ }^{\mathrm{I}}$

Vitoria's main ideas about political power are found in De potestate civili. This relectio may be considered, with due historical caution, as an embryonic Theory of the State. ${ }^{15}$ For the Dominican, all human groups need an authority responsible for pursuing the common good. To that end, God has conferred political power to the res publica (political community) that results from man's social nature. ${ }^{16}$ Therefore, that power ultimately resides in the political community: "since by natural and divine law is granted the power to govern the res publica and, apart from positive and human law, there is no special reason why that power should reside more in one than

\footnotetext{
I4) Truyol, A. "Razón de Estado y derecho de gentes en tiempo de Carlos V", Karl V. Der Kaisser und seine Zeit, Böhlaw Verlag, 1960, p. 205.

i5) See Gómez Robledo, A. Fundadores del Derecho Internacional, México, 1989, p. 30 and Truyol, A. "Razón de Estado ... ”, p. 205.

16) Vitoria asserted the natural origin of society vis-à-vis contractualist theses as other Spanish philosophers of the XVI century. See Hamilton, B. Political Thought ... op. cit. pp. 30-58.
} 
in the other, it is necessary for the community itself to suffice and to have the power to govern itself". ${ }^{17}$

Nonetheless, for Vitoria, the power of the monarch and that of the political community are not exclusive: political power resides in the res publica while its exercise is vested in the monarch; the administration of power, or government, is conferred upon the ruler by the res publica. Thus the Dominican ascribed a popular foundation for the monarch's power and likewise maintained that such power is limited by the mandates of divine, natural and positive law. Concerning the last, he made this observation: "civil laws are binding on legislators and principally on kings", so that "a legislator who does not obey his own laws wrongs the res publica and all other citizens". In short, "although the laws be issued by the king, they are equally binding upon the king himself". ${ }^{8}$

In this regard, Vitoria's theses differ from the principle princeps a legibus solutus est in Hobbes' Leviathan (165I), which the emerging states of the era sought to elevate. Whereas the friar maintained, like Hobbes, that it was the political community that should decide its government, he expressed a preference for, among the various forms of government, non-absolutist monarchy, an inclination that did not, however, prevent him from reserving certain decisions for the political community as a whole. Thus he made references to the majority principle for the appointment of rulers: "a res publica can appoint any one it will to be its lord, and therefore the consent of all is not necessary, but the consent of the majority suffices. For... in matters concerning the good of the res publica the decisions of the majority are binding even when the rest are of a contrary mind". ${ }^{19}$

Vitoria also reflected on the advisability in such cases of following the majority principle: if unanimity were to be required, the political community would not be adequately served, since it is rare and almost impossible to achieve, given the numbers of people involved. Thus it suffices for the majority to decide on something for it to be carried out lawfully". ${ }^{20}$ It may therefore be deduced that the political community is entitled to select its own government, with the injunction that, once this initial choice has been

\footnotetext{
17) Vitoria, F. "De potestate civili, proposition 7", in Obras ... op. cit.

18) Vitoria, F. "De potestate civili, proposition 2I", in Obras ... op. cit.

19) Vitoria, F. "De Indis recenter inventis, de tit leg, proposition I6", in Obras ... op. cit.

20) Vitoria, F. "De potestate civili, proposition I4", in Obras ...
} 
made, that government must be obeyed. As a result, the thesis offers new justifications for obedience to the law: power has its natural basis (albeit indirectly) in the political community itself. ${ }^{2 \mathrm{I}}$ In short, the friar addressed a variety of challenging political issues.

\section{The Res Publica of All the World}

Vitoria thought of the political community not only in individual local terms. His ideas integrate the res publica within a wider community of independent entities that together make up the entire globe and are subject to the rights and obligations deriving from the Law of Peoples. By virtue of this external dimension in his concept of political power, he could assert that the different political communities of the Orb constitute a single entity: Totus Orbis. This thesis diverges from the idea of a global political community ruled by Emperors or Popes and leans instead towards an order of communities as subjects who relate to each other horizontally, not on the basis of hierarchy.

Although Vitoria did not propose a particular mode of institutionalization for these ideas, there is nonetheless a strong connection between his conceptions of the Orb and the res publica: "Totus orbis, qui aliquo modo est una res publica". ${ }^{22}$ The Totus Orbis is conceived as a universal community of all peoples, extending to non-Christian political communities and reaching beyond the closed context of medieval Christendom and its idea of a community of European Christian kingdoms. ${ }^{23}$

In facing the issue of the Spanish conquest of the Indies, Vitoria maintained that no legitimacy could be derived from divine, natural or even positive law that would allow the Emperor Charles $\mathrm{V}$ to extend his sovereignty to other peoples. As the Indians were the original and true legitimate owners and lords of their land before the arrival of the Spanish,

21) For a commentary on Vitoria and Machiavelli's different approaches to the phenomenon of political community see the study by Truyol, A. "Razón ... op. cit.

22) On the parallelism see Barthelemy, J. "Francois de Vitoria", Les fondateurs du Droit international, A. Pillet (ed), 1904, p. 7 and Truyol, A. "El Derecho de Gentes como orden universal”, in La Escuela de Salamanca ... op. cit., p. 24.

23) On the issue of international subjectivity, commenting the relevance of Wolff and Vattel in this regard see Haggenmacher, P. "L'État souverain comme sujet de droit international, de Vitoria à Vattel”, I6 Droits II (I992): 20. 
in his opinion, "legal claims of title to their lands in favour of the Spanish monarchy have no more value than any title that they [the Indians] might have claimed had it been they who had discovered us [the Spanish]" ${ }^{24} \mathrm{He}$ held a similar position with regard to the Pope, who had no rightful power, beyond that of a strictly spiritual nature, over the Orb or any of its states. Thus he rejected the ideas of hierarchy and submission to the great powers pervasive in the res publica at the close of the Middle Ages. In sum, no power - be it papal or imperial - could claim universal authority.

Once questioning the status quo, he went further and outlined an alternative: a community of peoples encompassing the whole world. This is a striking seminal vision of the ideas of a "world political community" and "international law". The line of argument is clear: I) the people who make up any community need to be governed by a set of rules; 2) the multiple peoples of the world also make up a community; and 3) consequently, these are also meant to interact through a set of rules. That imagined (global) political community predates by two centuries the Civitas Gentium proposed by Kant and constitutes one of the first conceptualizations of an "international community".

Thus, from the jumble of Natural Law thought, the Dominican formulated quite a revolutionary idea. The closest precursor in the Western world is the Civitas Dei of Augustine of Hippo (345-430), that proposed, as an alternative to the Roman Empire, a plurality of peoples that coexist in peace within their natural borders, "as there are very many houses of citizens in a city" ${ }^{25}$ But it was in Vitoria's age that the idea of a worldwide order began to be formalized, in sharp contrast to previous ideas of segmented orders based on hierarchical (or non-egalitarian) criteria. $^{26}$

For Truyol, this vision amounts to "conceiving humankind as a moral person bringing together all states under Natural Law". The words of this historian of International law help to explain the significance of the Totus Orbis:

Without completely suppressing the idea of Christendom, so dear to the Middle Ages, and whose driving principle was the profession of a single shared religious faith, that idea, nevertheless, ultimately became the core of the system of international relations.

\footnotetext{
24) Vitoria, F. "De Indis, de tit non leg, proposition 7", in Obras ... op. cit.

25) Augustine of Hippo, City of God, IV, I5.

26) Truyol, A. "El Derecho de Gentes como orden universal" ... op. cit., p. I8.
} 
It was this idea that, in time, allowed the successive incorporation of non-Christian states into the international community, thanks to which International Law has a universal character. ${ }^{27}$

Francisco de Vitoria envisioned the 'rules of the game' for the world as a political community by reengineering the doctrine of the ius gentium. To this end, he modified the concept into something newly applicable as an instrument by which to regulate that world political community. Starting with the definition by Gaius (I60 AD) of the law of people ("the law that natural reason has established among all men"), Vitoria replaced the words "people/men" with the words "peoples/nations" and thus introduced a second sense to the classical concept of law for all mankind. Thus, in contrast to the Roman sense, Vitoria conceived the ius gentium as ius inter gentes ("law among peoples"): quod naturalis ratio inter omnes gentes constituit, vocatur ius gentium ("what natural reason has established among all peoples is called ius gentium"). This change in the Gaian definition of ius gentium ("inter omnes gentes" instead of "inter omnes homines") was instrumental to the development of the idea of international law.

Obviously, rules between societies predate Francisco de Vitoria. Their genesis is not to be found in academic scholarship, but rather in those political communities (/tribes) that forged agreements among themselves, throughout the five continents, since the dawn of civilization. ${ }^{28}$ The friar is obviously not intellectually responsible for the complex phenomenon of the development of those norms that political communities establish in their mutual relations. In addition, he had no intention of nurturing a general discourse on the foundations of a new world legal order. In fact, he grounded his ius gentium on a diffuse plurality of sources without a clear relationship among them: I) natural law; 2) custom; 3) 'original' social consent; 4) the consent of all peoples; 5) collective decision making (i.e. majority decision); etc. For Tierney, those categories were cited on a random basis. In his opinion, the friar displayed a "considerable versatility" in deploying norms of international law or "even in inventing such norms on occasion". ${ }^{29}$ However, it is precisely

\footnotetext{
27) Truyol, A. "Prémisses philosophiques du 'totus orbis' de Vitoria", 7 Anuario de la Asociación Francisco de Vitoria (1946-1947): 179.

28) See, in particular, Bederman, D.J. International law in Antiquity, Cambridge University Press, 2002.

29) Tierney, B. "Vitoria and Suarez on ius gentium ... op. cit. p. IoI.
} 
this inventiveness that was his genius.

Francisco de Vitoria reengineered several legal traditions to produce something new: ius gentium as ius inter gentes. That product of his political and legal imagination would pave the way to Grotius's conviction regarding the law of nations (De Jure Belli, I625): "fully convinced ... that there is a common law among nations, which is valid alike for war and in war". In conclusion, the professor from Salamanca gave birth to a big idea that many others, since then, have cultivated as a discipline and that has proved to be one of the most useful and now pervasive social artefacts of human progress.

Nevertheless, the relevance of Vitoria in the formation of this idea has been challenged in contemporary literature. The conventional academic authority in this regard is the German-born American jurist Arthur Nussbaum (I877-1964).$^{30}$ Essentially, Nussbaum argued in A Concise History of the Law of Nations that the substitution of "men" by "peoples" in the definition of ius gentium in the De Indis may well have been a faulty transcription, perhaps "a momentary flash of Vitoria's mind" (Ist edition) or even "a slip of memory" (2nd edition). ${ }^{3}$ However, the following line of the Relectio contains an express reference to the phrase apud omnes nationes ("among all nations"):

Quod naturalis ratio inter omnes gentes constituit, vocatur ius gentium. Sic enim apud omnes nationes habetur inhumanum sine aliqua speciali causa hospites et peregrinos male accipere.

In addition, these are the words of Vitoria, in his Commentary on the Summa Theologiae of Thomas Aquinas, referring to the inviolability of ambassadors: "et isto modo legati admissi sunt de iure gentium, et apud omnes nationes sunt inviolabiles". And finally, the following line in the Commentary makes the whole issue conclusive:

Ita de iure gentium dicimus quod quoddam factum est ex communi consensu gentium et nationum. ${ }^{32}$

30) See Cheatham, E.E., Friedmann, W.G., Gellhorn, W., Jessup, P.C., Reese, W.L.M., and Wallace, S.C. "Arthur Nussbaum: A Tribute" 57 Columbia Law Review I (I957): I-7.

31) See Nussbaum, A. A Concise History of the Law of Nations, Mcmillan (Ist Ed), I947, pp. 58-59 and (2nd Ed) 1954, pp. 80-8I.

32) See Vitoria, F. Comentarios a la Secunda Secundae de Santo Tomas, edition by Vicente Beltrán de Heredia, Vol. III, De Justitia, quaestio 57, Salamanca, 1934. 
In sum, the idea is certainly there: Vitoria was transforming the conventional meaning of ius gentium.

Nonetheless, determining what was the first intellectual formulation of such a far-reaching idea as "international law" is undoubtedly a sensitive cultural issue. Rossi's book on Brown Scott's "self-imposed mission" to trace the origins of international law to Vitoria is a good example. ${ }^{33}$ This persistent cultural issue is perfectly illustrated in the following crude and provocative conclusion of Topulos, interpreting the mentioned work of Rossi: "To a certain degree, Scott had a bias in favour of the Catholic view of the world, and therefore may have overemphasized the Catholic origins of international law. Vitoria was Catholic; Grotius was Protestant". 34

In any case, there are more promising approaches to Francisco de Vitoria and Hugo Grotius once the "who was first" question is left aside. For example, De Indis did not result from any consultation requested by Charles $\mathrm{V}$ but was clearly aimed to provide him with theological guidance on the Indies while Grotius's Mare Liberum (1609) resulted from a legal brief, De Jure Praede (On the Law of Spoils), ${ }^{35}$ originally written on behalf of the Dutch East India Company, an early 'globalised company'. In fact, the plea for the freedom of the seas followed a request by the executives of the company. ${ }^{36}$ Therefore, two of the first key documents of the history of international law as a discipline were written under the shadow of great global players of that age: an Emperor and a corporation.

Another interesting approach is that Vitoria's document was a university conference written in the tradition of theological thought while Grotius's initial legal document (De Jure Praede) was originally written by commission (legal brief). Thus the orientation of Mare Liberum and De Indis is naturally different. Grotius himself illustrated this point. In I6I3, on a Dutch diplomatic mission to resolve matters of monopoly and other commercial activities in the East Indies, he was challenged by the English with a quote

33) See Rossi, Ch. Broken Chain of Being: James Brown Scott and the Origins of Modern international law, Kluwer Law International, 1998, p. 7.

34) Topulos, Kh. "Book Review", 28 International Journal of Legal Information (2000): I50.

35) See Anand, R.P. Origin and Development of the Law of the Sea, Martinus Nijhoof Publishers, I982, pp. IO-I23.

36) See Van Ittersum, M.J. Profit and Principle: Hugo Grotius, Natural rights theories and the Rise of the Dutch power in the East Indies 1595-1615, Brill Academic publishing, 2005, pp. XIX-LXX 
from his own anonymously published Mare Liberum. Grotius responded by stating that contracts with natives have precedence over the law of nations, adding that the anonymous author would most certainly agree with him. ${ }^{37}$

In short, there are more interesting issues to address than the merely foundational question. In any case, that question is addressed with a reasonable statement from Verhoeven: "We should not ask of Vitoria more than he can give. The Law of Peoples is still there in his utterings. The essential thing is nonetheless in place." In the balanced opinion of this historian, Francisco de Vitoria basically "sets the stage" in such a way that the central theme would become international law. However, Vitoria merely wrote the "prologue". ${ }^{8}$

Thus, the ideas of Vitoria opened the way for a new discipline: the study of the rules that govern the relations among political communities. In opening this path, he inaugurated the 'invisible college of international lawyers'. ${ }^{39}$ In any case, the discipline is obviously, in the words of Haggenmacher, a "collective creation"..$^{\circ}$ Every new idea is the fruit of a collective intellectual quest that allows the contemporary man to build upon the past. ${ }^{41}$ Thus, classic international law was born of an aggregate of influences; but for this, Vitoria certainly did his part by pointing out and opening new paths for others.

The man who first suggested the idea of international law as a discipline was certainly the friar (by reengineering Aristotelian-Thomist philosophy, Roman law and the ius commune) while the first systematizer of the new discipline is Hugo Grotius. Brown Scott's definition of the latter thinker is certainly accurate: a "master compiler and expounder". ${ }^{42}$ In essence, the Dutch attorney "worked out" the ideas of Vitoria and others in writing the first widely recognized "product" of the new legal discipline: the Mare Liberum.

\footnotetext{
37) See Anand, R.P. Origin and development ... op. cit. pp. 96-97.

38) Verhoeven, J. "Vitoria ou la matrice du droit international”, Actualité de la pensée juridique de Francisco de Vitoria, Bruylant, 1998, pp. 97-I28.

39) On the idea of the invisible college in general see Owen, G. The Book Nobody Read: Chasing the Revolutions of Nicolaus Copernicus. Penguin Books, 2004 (Chapter II).

40) Haggenmacher, P. "La place de Francisco de Vitoria ... op. cit. p. 36.

41) See Mondolfo, R. Figuras e Ideas en la Filosofia del Renacimiento, Buenos Aires, I954.

42) Brown Scott, J. The Spanish origins ... op. cit., p. 52I-522.
} 
Let us now examine in depth these new ideas. According to Vitoria, the Orb "has the right to make laws that are just and appropriate for all, such as the law of peoples ... and no kingdom may lawfully exclude itself from the law of peoples because it is ordained by the authority of the Orb as a whole." 43 For the Dominican, ius gentium is a set of universal norms that regulate the relations among peoples. Its foundations sometimes stem from natural law, and at other times, from positive law. ${ }^{44}$ Thus, in certain passages ius gentium arises as positive law from the "mutual consent of peoples and nations" ("ex communi consensu omnium gentium et nationum") while in others, it is based on natural law. 45 The consensus-based approach was later developed by authors such as Suarez and Grotius who separated the ius gentium from natural law by maintaining that the latter is a law comprising the unwritten customs among nations.

The ideas of ius inter gentes and the res publica of the whole world (Totus Orbis) are intellectual constructs that may be understood as by-products resulting from the Encounter between the Old and New World. The age saw a flourishing of utopian thinking with social rules and consequently law as a central part of those new social visions and conceptions. ${ }^{46}$ Friars were no strangers to those currents of creative thought that produced masterpieces like the Civitas solis, poetica idea Reipublicae philosophicae (1623) of the Dominican Tomasso Campanella (I568-I639). That fictional account of a sailor landing on the island of Taprobana is obviously a blend of sociological creativity with the chronicles of the men that reached the New World. Furthermore, a significant portion of those reaching the New World were also motivated by utopian thinking (i.e: the New Jerusalem, etc).

That was particularly the case of many members of religious orders. A vivid example of the power of that motivation was the fascinating diary of the voyage of a group of I6 Dominicans to Chiapas that left San

43) Vitoria, F. "De potestate civili, Proposition 2I", in Obras ... op. cit.

44) Vitoria makes a distinction between three categories of law: divine law, human law and natural law. See Rubin, A. "International law in the age of Columbus", 39 Netherland International Law Review (1992): 5-35.

45) See Vitoria, F. Comentarios a la Secunda secundae de Santo Tomas, edition by Vicente Beltrán de Heredia, Vol. III, De Justitia, quaestio 57, Salamanca, I934, p. I5.

46) See Ramiro, M.A. Utopia y Derecho: El sistema jurídico en las sociedades ideales, Marcial Pons, 2002. 
Esteban (Salamanca) on January I2, I544. ${ }^{47}$ Utopian thinking also directly influenced the higher ranks of the Church in the Indies. In fact, the first Bishop of México himself, Fray Juan de Zumárraga, possessed a heavily annotated copy of Thomas More's rationalist fantasy, Utopia (I5I6). ${ }^{8}$ It is also noteworthy, in this regard, that Zumárraga was the man who advised the Emperor Charles V to consult Francisco de Vitoria on some theological issues concerning the Indies.

In sum, the need to formulate responses to the new challenges posed by the Encounter of the New World led Vitoria, like others, to stretch imagination. It is through this intellectual voyage to the unknown that he arrived at notions instrumental to the construction of the secular law of nations. The blackfriar made additional contributions that are also worthy of mention. His natural law conception of ius gentium is of special interest. In this particular area, one of the most challenging ideas offered by the friar is that of the ius communicationis: a defense of the natural right to free communication among peoples and nations. This idea connecting to the ius humanae societatis of Giovanni d'Andrea (I275-I348) allowed for a new approach to the relations among peoples. ${ }^{49}$

Vitoria initiates the ius communicationis argument with the following statement: "the first proof comes from the law of peoples which either is natural law or derives from natural law ... Among all nations it is considered inhumane to treat guests and travellers badly without special cause". This is where the Dominican suggests the possibility of "just titles" for the conquest of America. The matter is summed up in this statement: "the Spanish have a right to travel into the lands in question and to sojourn there, provided they do no harm to the natives, and the natives may not prevent them.. ${ }^{\circ} \mathrm{He}$ likewise proceeded to enumerate a series of specific universal rights derived from the ius communicationis: "all persons have the right to migrate to any nation, to live there for the duration they so desire, and not to be expelled there from in times of peace without just cause; they have the right to trade freely with other nations and to participate in property held in common".

47) See De la Torre, T. Diario de Viaje: De Salamanca a Ciudad Real de Chiapa I544-I545 (Cándido Aniz Ed), Ed.OPE, 1985.

48) Pagden, A. Political imagination ... op. cit. p. 25.

49) Truyol, A. "Vitoria et la tradition scolastique" ... op. cit. p. 8I

so) Vitoria, F. "De Indis, de tit leg, Proposition 2", in Obras ... op. cit. 
Furthermore, the friar proclaimed that certain things are not subject to appropriation: "if there are among the Indians any things which are treated as common to both citizens and strangers, the Indians may not prevent the Spanish from communication and participation in them." ${ }^{1}$ He likewise suggested and defended the freedom of navigation and commerce, freedoms intimately linked to human communication and cooperation: "by natural law water and the sea are common to all, so are rivers and harbours, and by the law of nations ships from all parts may be moored there; and on the same principle they are public things. Therefore it is not lawful to keep anyone from them." 52 In addition, he defended free trade by asserting that "neither may the native princes hinder their subjects from carrying on trade with the Spanish, nor, on the other hand, may the princes of Spain prevent commerce with the natives." 53 Therefore, it is reasonable to sustain that this 'basket of rights', woven from the natural right of communication, is of universal projection.

This ius communicationis implied for the Dominican the right to travel (ius perigrinandi) as well as the right to trade and the right to preach (ius praedicandi) without interference. The deprivation of the natural rights conferred by the ius gentium would constitute an iniuria. Consequently, the Spanish could enforce these rights even if opposed by the Amerindians. In the mind of Francisco de Vitoria, those were the legitimating grounds for the presence of the Spanish in America. As a logical result, this title is a cornerstone of his thinking concerning relations among peoples. However, as Pagden points out, this "right to society and natural communication' (naturalis societas et communicationis) has received less attention than others, although it certainly appears to a be a "title" of his own invention. ${ }^{54}$ In his opinion, Europe turned a deaf ear to the idea of this right despite its power and originality. For Pagden, the reason is simple: the possibility that a vaguely defined notion of "human communication", or the mere principle of hospitality, could become a principle of law might threaten the whole system of sovereignty emerging at the end of the i6th century, a system in which the rights of sovereignty, according to Thomas Hobbes,

\footnotetext{
si) Vitoria, F.”De Indis, de tit leg, proposition 4”, in Obras ... op. cit.

52) Vitoria, F. "De Indis, de tit leg, proposition 2", in Obras ... op. cit.

53) Vitoria, F."De Indis, de tit leg, proposition 3", in Obras ... op. cit.

54) Pagden, A. La ilustración y sus enemigos, Península, 2002, p. IO2.
} 
were "indivisible and incommunicable". 55 In essence, if the new emerging nation-states were to protect their borders, limitations to the free movement of persons could not be questioned. ${ }^{6}$

In consequence, following Pagden's argument, although Vitoria failed to establish this right, he developed a language of great potential that Kant -without having read Vitoria- would revive in similar terms. ${ }^{57}$ More than two hundred years later, the ius cosmopoliticum of the Perpetual Peace (I795) focuses on the "conditions of universal hospitality", and confers a precise meaning to "hospitality". For Padgen, Kant's "hospitality" is the old Spanish friar's right of all persons to freely move about in the world..$^{8}$ This is certainly an interesting interpretation

However, the title of ius communicationis has also been interpreted in a rather opposite sense. Tierney suggests, for example, that Vitoria seems to have abandoned caution and instead "displayed a rather bold creative imagination in discovering or inventing new rights for the Spanish within the law of nations" (emphasis added). Vitoria claimed that the ius communication conferred these rights upon the Spanish "even without consent" (of the Indians) and granted them the right to use force if these rights were violated. In Tierney's opinion, "as the argument goes on it becomes more and more unpersuasive, not only to the modern reader [but even to his] immediate successors at Salamanca" ${ }^{59}$ And here, Tierney recalls the famously sarcastic statement of one of Victoria's favourite disciples, Melchor Cano, who observed that the Spanish did not enter the Indian lands merely as travellers, "unless we call Alexander [the Great] a traveller". ${ }^{60}$ Evidently, the controversy over the ius communicationis has always been there and still permeates academic references to the works of the Dominican.

\footnotetext{
55) See Hobbes, T. Leviathan, Part II, Chapter XVIII.

56) Pagden, A. La ilustración ... op. cit. p. IO2.

57) Pagden, A. "El ideal cosmopolita, la aristocracia y el triste sino del universalismo europeo", I5 Revista internacional de Filosofía Politica (2000): 2I-4I.

58) Pagden, A. La ilustración ... op. cit. p. Io8.

59) Tierney, B. "Vitoria and Suarez on ius gentium, natural law, and custom", The Nature of Customary Law: Legal, Historical and Philosophical Perspectives (A. Perreau-Saussine and J. Bernard Murphy Eds), Cambridge University Press, 2007, p. I09.

6o) Cano, M. "Dominio Indorum", De bello contra insulanos, Corpus Hipanorum de Pace, Vol. IX, CSIC, I982, p. 579.
} 


\section{Structures of the Law of War}

The ius communicationis connects with several of Francisco de Vitoria's major ideas on the law of war. For the friar, the right to travel peacefully and to "enjoy hospitality" is part of the law that has survived from the dawn of society. Thus, an infringement of this law is a just cause for war. This is also an area in which the Dominican made seminal contributions to the development of the discipline of International law. ${ }^{61}$ In fact, the Dominican is widely recognized for his reflections on the law of war in De Indis sive de Iure Belli hispanorum in Barbaros.

In the years after 1516, conquests by the Ottoman Empire in the eastern Mediterranean and the Balkans revived the ideal of the res publica Christiana based on a desire for peace within the Christian World (wars of religion) and a pressing need for a common front against the Turks. However, the conflict between Francis I and Charles V for hegemony in Italy made it impossible to develop that common front.

Vitoria's major contributions to the development of the law of war are the systematic formulation of the conditions required for a just war and the universal application of these formulas (both to Christians and infidels) on the basis of natural law. ${ }^{62}$ Thus he inaugurates this early systematization of the law of war by opposing the unconditional right to war against infidels such as that defended by Henry of Susa, Bishop of Ostia (I200-I27I). For the Dominican, in sharp contrast to the positions of Hostiensis, war is a means for righting wrongs. Therefore, he explored issues such as: I) what circumstances make war lawful; 2) who has the authority to declare war; 3) what actions are lawful during war; and finally, 4) what are the just causes for going to war. In sum, Francisco de Vitoria framed the problem of war as a question of justice; and thereby, this conceptualization was an important step towards its restriction. ${ }^{63}$

In his response to these questions, the Dominican distinguishes between the laws justifying war (ius ad bellum) and the laws governing war (ius in bello). This fruitful distinction, envisaged early on by men like Augustine of Hippo still govern some of the inner workings of international law concerning the use of force and international humanitarian law. Francisco

\footnotetext{
61) Haggenmacher, P. "La place de Francisco de Vitoria ... op. cit. p. 76-77.

62) Truyol, A. "Vitoria et la tradition scolastique" ... op. cit. p. 82

63) Solages, B.D. La théologie de la guerre juste, Paris, I946, I8.
} 
de Vitoria applied the concepts of defensive and offensive war to analyze the lawfulness of war. According to the friar, defensive war is always lawful under natural law, while offensive war is to be undertaken only as a response to an unlawful action. The Dominican further reasoned that the only just cause for the declaration of war is having been seriously injured. Moreover, under his weltanschauung, wars of expansion are not just wars. In fact, conquered territories could not be annexed nor could wars waged for "the glory and benefit of princes" be considered just. In addition, Vitoria also rejected private wars and maintained that the authority to declare war resided exclusively in the prince.

For Vitoria, peace was already a societal value to be taken into account seriously in the making of decisions. Thus, a caveat was added: the immediate purpose of war was to preserve the peace and security of the res publica. For the Dominican, war must have as its central purpose the "common good of Totus Orbis". In consequence, this "common good" becomes a criterion for determining whether to go to war or to refrain from doing so. Vitoria likewise attempted to mitigate the effects of war on the civilian populace (ius in bello) by following Alexander III's distinction between the innocent (innocentes) and the guilty (nocentes). Under this conception, women, children, foreigners (hospites) and the civilian population (gente togata et pacifica) were considered innocents and thus could not lawfully be killed by combatants. In addition, the friar defended the idea of treating prisoners as innocents, while enumerating the exceptions in which it was lawful to execute them.

Prompted by the news of the fate of the Indians in the Yucatan, Vitoria reflected upon the need to defend innocent people from the "tyranny and oppression" of their lords. At the same time he took into account the practices of some American Indian peoples, such as human sacrifice and cannibalism. ${ }^{64}$ In such cases, he maintained that it was lawful for other peoples to intervene (go to war) in order to prevent those practices, since these were violations of natural law and the law of peoples. ${ }^{65}$ The Dominican also defended the lawfulness of deposing Amerindian rulers in such cases. Before that is done, however, an initial attempt should be made to intimi-

\footnotetext{
64) Vitoria, F. "De Indis recenter inventis, proposition I5", Obras ... op. cit.

65) Vitoria, F. "De Indis recenter inventis, proposition Is" and "De Temperantia", proposition 7", Obras ... op. cit.
} 
date them into abandoning such practices; but if that was not successful, war had to be declared on them and, thereafter, their rulers deposed. To these just grounds for deposition, Vitoria added two more: "because of the number and aggravated quality of the damages and wrongs which have been wrought or, especially, when security and peace cannot otherwise be had of the enemy and grave danger from them would threaten the state if this were not done". ${ }^{66}$

Thus Vitoria speculated that the ius gentium might permit peoples in one part of the world to intervene in the affairs of peoples in another on strictly humanitarian grounds. Under this conception, the power of Princes is transformed into an instrument for the common good of the whole world: "since the res publica is part of the entire globe and a Christian province principally part of all of the res publica, if war is of use to a province or even more to a res publica, but injures the world or Christendom, I think for that reason it would be unjust." ${ }^{67}$ Thus, as Barbier points out, the Dominican ascribes universal dimensions to the res publica, wherein the princes are "responsible for the protection of the whole world and for the common good of humankind". ${ }^{68}$

In essence, De Indis sive de Iure Belli hispanorum in Barbaros is a welldeveloped theorization of the law of war. In fact, it is one of the central inspirations for Grotius's De Jure Belli Ac Pacis. To the modern mind, the conception of war in these works is of course over-simplified, with the striking belief, as Hamilton puts it, that one side must be in the right and most of all, that a 'just' prince could take the place of a judge. ${ }^{69}$ However one sees it, those ideas were remarkably advanced for an age in which war was generally considered a natural legal mechanism to resolve disputes among princes.

The impetus for this theorization of the law of war was the Dominican's particular concern over the actions of the Spanish in the American Indies as well as over the devastating religious wars in Europe. In particular, Francisco

66) Vitoria, F. "De Indis sive de Iure Belli hispanorum in Barbaros, proposition 59", Obras ... op. cit.

67) Vitoria, F. "De potestate civili, proposición I3", in Obras ... op. cit.

68) Barbier, M. "La notion de respublica chez Vitoria”, (Yves Charles, Ed), Aspects de la pensée médiévale dans la philosophie politique moderne, PUF, I999, 96-97.

69) Hamilton, B. Political Thought in Sixteenth-Century Spain ... op. cit., p. I70. 
de Vitoria strongly opposed the struggle between the Habsburg and ValoisAngoulême dynasties, and in consequence Charles V's entire policy towards France. As he stated in his private correspondence, "wars were not invented for the good of princes but rather of their peoples; and if this be true, as it is, consider well men of good will, if our wars be for the good of Spain, or France, or Italy or Germany, and not to the destruction of them all."70

In fact, not only did Vitoria express his critical ideas concerning this state of affairs in the Relectios, but he personally advocated for peace in his private contact and correspondence with the notables of Spain. The correspondence between the friar and his friend Don Pedro Fernández de Velasco, Condestable of Castile and Count of Haro, is illustrative in this regard; Vitoria writes,

It is well-known how little heed princes pay to anyone's recommendations, especially if they lie not within their inclination, but if any might occasion his Majesty, none more than [your Lordship] by your many titles...I think it may go hard, but if a way could be found to give some pause between his Majesty and the King of France, I believe that would be an even greater victory than the battle of Tunis. ${ }^{71}$

The Dominican strongly opposed Charles V's attempt, in 1538, to obtain new war taxes. That same year, at the Courts of Toledo, Vitoria's friend Don Pedro responded to the imperial demands that a general tax be approved to fund the wars in Europe with these bold words, addressed to the Emperor himself:

It is of the utmost importance ... that you likewise be entreated to work towards universal peace with all for a time. For be the war upon the infidels ever so just, peace is often to be had with them, as was had by the kings of Castile with the kings of Granada.

As might be expected, the Condestable of Castile's speech enraged Charles V so much that he suspended the sessions and even threatened to throw Don Pedro to the corridor with his own hands..$^{72}$ In fact, that was the last time that notables and prelates would be represented in the Courts of Toledo.

70) Getino, L.G. El Maestro Fr ... op. cit. p. 218.

71) Getino, L.G. El Maestro Fr ... op. cit. p. 220-22I.

72) The answer of Don Pedro was audacious: "Mirarlo ha mejor Vuestra Majestad, que si bien soy pequeño peso mucho". See Sandoval, P. Historia de la Vida y Hechos del Emperador Carlos 


\section{Doubts on the Indies}

Not only was Francisco de Vitoria critical of the decisions taken by the monarch concerning the res publica of Spain, but he also disagreed on the American Indies. The blackfriar had access to accurate information on the actions of the Spaniards in those lands. His own sources of information were the first-hand accounts of objecting missionaries, as well as those of soldiers that contacted the University of Salamanca to consult on moral and legal issues related to the conquest. ${ }^{73}$

Vitoria's first references to the Indies appeared in his lectures of 1535 and I536. However, before these, Vitoria had already written the following lines in a private letter to his friend Manuel de Arcos, Prior of the College of San Gregorio (Valladolid):

The things that I learn [concerning the events involving the peoples of Peru upon the arrival of Spanish] no longer horrify or embarrass me, except the trickery and profiteering and things of the Indies [(trampas y beneficios y cosas de Indias)], which make my blood freeze on just hearing of them (I534). ${ }^{74}$

In this letter, Vitoria stated that there may be people who would excuse and praise those "events, killings and spoils". He, on the other hand, refused to defend those men he labelled with the derogatory term peruleros. Thus the blackfriar expressed his consternation about excusing them:

I contrive to do likewise with the peruleros, although they are few, yet some come by here. I do not declare nec excito tragoedias against the ones nor against the others, but rather, since I cannot pretend, nor say nothing more, but that I do not understand it, and scarce can see the justice or certainty in it, that they consult with others who might better comprehend it.

His strong objection in this regard was made even more manifest with: "May my tongue and my hand wither if I speak or write anything so inhuman and apart from all Christianity."75 The last statement of his letter clearly

\footnotetext{
$V$, Libro 24, Año I538, n. VIII, I6I4.

73) Getino, L.G. El Maestro Fr ... op. cit. pp. 99-Ioo.

74) Vitoria, F. "Carta de Francisco de Vitoria a Manuel de Arcos sobre negocios en Indias", Corpus Hipanorum de Pace, Vol. V, CSIC, 1967, p. 137.

75) Vitoria, F. "Relectio de Indis", Corpus Hisparorum de Pace, vol V, CSIC, I967, p. I37.
} 
captures his position, and also the social challenge posed by the encounter of the Old and New World:

In truth, if the Indians are not men, but monkeys, non sunt capaces iniuriae. But if they be fellow humans, et quod ipse prae se ferunt, vassals of the Emperor, I do not see how to excuse these conquerors of such ultimate impiety and tyranny, nor do I see what great service they render his majesty by laying to waste his vassals. ${ }^{76}$

This passage contains a blend of medieval legal categories, anthropological reflections and moral and religious concerns that captures the mentality of this man of the I6th century. These private reflections represent the wide mixture of concerns, motives and legal foundations that would later give shape to such a groundbreaking text as De Indis. It is important to recall that it was a time of great uncertainty in which the very humanity of the American Indian was a matter of doctrinal controversy, and continued to be so even after the papal bull Sublimis Deus (I537). These private reflections of Vitoria would soon find their way to public audience through a series of lectures and conferences. In fact, the first De Indis contains an express comment on the newness of the issue in the world of the written word: "It must be kept in mind that I have seen nothing written on this question."

The text condenses some of Vitoria's most powerful ideas on the Amerindian character, their relations with the Spanish, and the Crown's titles to the New World. The Relectio follows the typical structures of argumentation of Scholastic thought. It divides, however, into two sections that are incompatible: one is stating that the Spanish had no right to conquer those territories, and the other is pondering several possible "just titles" ${ }^{77}$ As such, the blackfriar begins the first part of his commentary with this statement: "from all I have heard, there is no doubt that the Indians were "publicly, privately, and peacefully in possession of their things" before the arrival of the Spanish. Thus, the possible grounds on which to allege that the Indians were not the rightful masters of their lands (dominium), but "barbarians", was that they were either I) sinners, 2) infidels, 3) insensate, or 4) amentes (idiots). In response, Vitoria decides to assess these titles in

\footnotetext{
76) Vitoria, F. "Relectio ... op. cit. p. I38-I39.

77) Cavallar, G. "Vitoria, Grotius, Pufendorf, Wolff and Vattel: Accomplices of European Colonialism and Exploitation or True Cosmopolitans", Journal of History of International Law Io (2008): 209.
} 
detail and concludes that being in a state of mortal sin does not preclude ownership, ${ }^{78}$ nor does unbelief, ${ }^{79}$ nor their potentially barbarian condition, their "want of reason", or their "unsoundness of mind" ${ }^{80}$ Therefore, none of these "titles" could provide the Castilian crown with dominion in America. ${ }^{81}$

This line of reasoning has led some academic literature to attribute to Vitoria a defence of the legal equality of peoples. ${ }^{82}$ However, he does make statements in both directions, as the "just titles" in the second part of the Relectio (i.e: ius communicationis and ius praedicandi) clearly illustrate. ${ }^{83}$ For the Dominican, for example, "Christians have the right to preach and publish the Gospel in the lands of the barbarians." ${ }^{4}$ As a result, Vitoria deduces the following conclusion:

if the Indians, whether it be their lords or the populace, prevent the Spanish from freely preaching the Gospel, the Spanish, after first reasoning with them in order to quell objections, may preach it despite their unwillingness and devote themselves to the conversion of the peoples in question, and if need be they may then accept or even make war, until they succeed in obtaining facilitation and security for preaching the Gospel. ${ }^{85}$

Furthermore, Vitoria speculated on the hypothetically exclusive right of Spain to evangelize, since "although it is a task common and permitted to all, yet the Pope may have entrusted it to Spain and forbidden it to all others" ${ }^{86}$ That position is self-explanatory if we contextualize the man: Francisco de Vitoria was a Friar Preacher, a member of the Ordo Praedicatorum. This Order, in addition to being a traditional defender of Orthodoxy, sent a significant contingent of its members to evangelize the New World as missionaries. Thus it should come as no surprise that the "Spanish obligation to missionize",

\footnotetext{
78) Vitoria, F. "De Indis recenter inventis, proposition 6", Obras ... op. cit.

79) Vitoria, F. "De Indis recenter inventis, propositions 7-Io", Obras ... op. cit.

80) Vitoria, F. “De Indis recenter inventis, propositions I9-23", Obras ... op. cit.

8I) Pagden, A. Political imagination ... op. cit. pp. I5-2I.

82) Truyol, A. "España ... op. cit., p. 8.

83) Vitoria, F. "De Indis recenter inventis, propositions I-8”, Obras ... op. cit.

84) Vitoria, F. "De Indis recenter inventis, proposition 9", Obras ... op. cit.

85) Vitoria, F. "De Indis recenter inventis, propositions 9-I2", Obras ... op. cit.

86) Vitoria, F. "De Indis recenter inventis, proposition Io", Obras ... op. cit.
} 
as Cavallar puts it, ${ }^{87}$ is central to the construction of De Indis. Within this contextualization, the genesis of the title of ius praedicandi becomes clear.

His defense of the ius praedicandi is certainly not a major contribution to the history of ideas. However, his analysis and rejection of those doubtful titles concerning the alleged incapacity of the American Indians surely is. For this analysis, Francisco de Vitoria made a full anthropological sketch of these peoples and their communities on the purely rational basis. The argument he considered, "though certainly not asserting it with confidence", is as follows: "although the Indians in question are not wholly unintelligent, yet they are not far from that condition, and thus are unsuited to establish or administer a commonwealth both legitimate and ordered in human and civil terms". Following this line of reasoning:

it might, therefore, be maintained that in their own interests the princes of Spain might undertake their administration, providing them with prefects and governors for their towns, and even giving them new lords, so long as this be to their benefit... Such an argument might be based on the precept of charity, they being our neighbours and we being bound to look after their welfare. Let this, however, as I have already said, be put forward without dogmatism and subject also to the limitation that any such interposition be for the welfare and in the interests of the Indians and not merely for the profit of the Spaniards. ${ }^{88}$

The Dominican did consider, however, the possibility that the Indians' capacity to govern their life and affairs might be less than fully developed; in that case, some sort of tutelage might possibly be imposed over them until they reached the 'age of reasoning'. However, Vitoria did not endorse this assessment, but neither did he condemn it. He spoke to the matter in the following vein:

The truth of the matter is that they are not of unsound mind but have, according to their kind, the use of reason. This is clear, because there is a certain method in their affairs; they have polities which are carefully arranged and they have definite marriage and magistrates, overlords, laws, and workshops, and a system of exchange, all of which require the use of reason.

87) See Cavallar, G. "Vitoria, Grotius ... op. cit. p. I89.

88) Vitoria, F.”De Indis recenter inventis, proposition I8”, Obras ... op. cit. 
Consequently, Vitoria does not associate their apparent lack of reason to any inherent defect of nature: "accordingly I for the most part attribute their seeming so unintelligent and simple-minded to a bad and barbarous upbringing, for even amongst us there are many peasants who differ little from brutes". ${ }^{89}$

In the analysis of the blackfriar, the Indian is like a grown child whose rational potential is not yet developed. ${ }^{\circ}$ However, he strongly rejected the Aristotelian idea of natural slavery, ${ }^{9 \mathrm{I}}$ later supported by Hostensis as well as Juan Gines de Sepulveda, the Erasmist author of Democrates Alter. For Vitoria, on the other hand, the Indian was to be considered as a rational being. As such, Vitoria claimed American Indians' right to be treated as humans..$^{92}$ The uncivilized Indian, not being inferior by nature, is therefore not subordinate to civilized men, but must be educated, and thus made civilized. As he stated at the end of the lecture, if it is true that the Amerindians live "almost like beasts and wild animals", this is not because of their lack of rationality but because of their "poor and barbarous education".

In sum, the viewpoint he expressed was patently paternalistic; and although it is connected to the idea of equality among men, it is biased in favour of Europeans who must care for and educate the Indians. His position is illustrated with an artificial construct: a land in which all adults have perished and only children and adolescents have survived. In that scenario, the European princes should care for and govern them while they be in such a state. ${ }^{93}$ By analogy, the same treatment should be afforded to the Indians.

However, he does not assert this "possible title" with confidence. Thus Vitoria postulates it for the sake of the argument: "this is another title which indeed cannot be confirmed, but rather brought up for discussion, and some think it a lawful one. I dare not affirm it at all, nor do I condemn it entirely." 94 Certainties coexist with doubts in the texts of the blackfriar.

\footnotetext{
89) Vitoria, F.”De Indis recenter inventis, proposition 23", Obras ... op. cit.

90) Pagden, A. The fall of natural man. The American Indian and the origins of comparative ethnology, Cambridge University Press, 1982, p. I04.

9I) See Aristotle. Politics, Harvard University Press, 1977.

92) Hamilton, B. Political Thought ... op. cit., p. I69.

93) Vitoria, F. "De Indis sive de Iure Belli hispanorum in Barbaros, proposition I8", Obras

... op. cit.

94) Vitoria, F. “De Indis recenter inventis, proposition I8”, Obras ... op. cit.
} 
This public and open questioning by a Theologian of great recognition was a major historical step in the process of applying reason to the relations among peoples.

In addition, he also considered the crucial issue of property rights - dominium rerum in the language of natural jurisprudence -95 of the Spanish vis a vis the Amerindians. ${ }^{96}$ And here, the text of De Indis is both precise and particularly impressive: "Let us finally conclude: that prior to the arrival of the Spanish in the Indies the barbarians were publicly and privately [the] true lords [of their lands]." As Pagden explains, the Relectios of the blackfriar left the Castilian crown with only "a slender claim to jurisdiction (dominium jurisdictions) in America, but no property rights whatsoever". ${ }^{97}$

On one hand, Francisco de Vitoria propounded a series of natural law foundations questioning the expansion of power and authority of both the Emperor and the Pope, while on the other hand formalizing just titles to protect the channels of social communication and interaction of the Spanish with the Amerindians. In this intellectual process, the rational capacity he attributed to the American Indians led him to defend their public dominion and natural property rights. However, while he recognized the cultural and institutional sophistication of some of these peoples, he considered (but did not endorse) the advisability of establishing a system of tutelage for some of those peoples ("barbarians") as a paternalistic, provisional solution to repair their backwardness through education.

\section{Ideas Meet the Status quo}

The Encounter stands out as one of the most convulsive events of the transition to modernity. It marks a watershed in the history of ideas in having changed the way mankind sees the world. From the I530s on, the Conquest became a subject of heated debate in universities: the complex intellectual challenge of understanding the Encounter would produce several new legal

\footnotetext{
95) See generally Spicq, C. "La notion analogique de dominium et le droit de proprieté", 20 Revue Sciencie, Philosophie et Theologie (193I): 52-76.

96) Pagden, A. "Dispossessing the Barbarian: The Language of Spanish Thomism and the Debate over the Property Rights of the American Indians" in The Language of Political Theory in Early-Modern Europe, (Anthony Pagden ed), Cambridge University Press, 1987: 79-98.

97) Vitoria, F. Political Writtings (Anthony Pagden and Jeremy Lawrence eds), Cambridge University Press, I991, p. xxvii
} 
and political ideas. This issue was certainly not within the natural realm of a traditional academic mind of the period. New paths had to be opened, and not without difficulty.

Compelled by dramatic events and conscious of the moral dimension of academic work, the blackfriar took action with words. As Villey puts it, Catholic Spain expected a great deal from its theologians at this crossroads and the friar felt the need to participate by counselling the men of action, such as the missionaries and Bishops in America. ${ }^{98}$ Paraphrasing Truyol, the Dominican rejected the "flight from reality" of previous Scholasticism. ${ }^{99} \mathrm{He}$ rejected its traditionally abstract type of speculation in favour of analysing social life with an abundance of data, erudition and imagination.

The Dominican's questioning of the status quo was a expression of his moral and intellectual integrity: "I can defend nothing other than what I have said" (Sed ego hactenus non possum aliud intelligere nisi quod dictum est). By questioning, the friar revealed himself to be an early critical thinker; only a highly recognized theologian, or a favoured court jester (i.e: Francesillo), ${ }^{100}$ would have dared to express himself so freely with respect to issues such as the just titles of the Emperor. In this sense, while Vitoria is not exactly a prime example of "academic freedom", he was sufficiently protected in institutional terms, being a university professor, theologian and member of an order, to make some major intellectual leaps. He was in a privileged position to explore, with a degree of liberty, the relationships between moral concerns, 'revealed truths' and secular ideas under the authoritative framework of Theology, the "supreme science". By virtue of speaking the several languages of theology, morality and reason, he was able to bridge the old and the new conceptions.

These new intellectual frontiers would also be crossed by his brothers at San Esteban. Because the Dominicans had been the first to join the project of the new evangelization in America, the friars at home in San Esteban would be amongst the first to learn of the crude realities of the Conquest

98) Villey, M. La formation de la pensée juridique moderne, Éditions Montchrestien, I968, p. 357 .

99) Truyol, A. "Vitoria et la tradition scolastique", op. cit. p. 7I.

го) Zúñiga, Francesillo de, Crónica burlesca del emperador Carlos V (Diane Pamp de AvalleArce, Ed), Crítica, 198I. See also Bouza, F. Locos, enanos y hombres de placer en la Corte de los Austrias. Oficio de burlas, Temas de Hoy, I99I. 
in the accounts of their brothers in the New World. ${ }^{\text {Ior }}$ The coming and going of missionaries offered them an extensive knowledge of that reality.

In 1535 , Vitoria's disciple Domingo de Soto (I495-1560) presented a Relectio entitled De Dominio where some of the first doubts concerning the affairs of the Indies are first raised: "By what right do we take possession of the transatlantic Empire so recently discovered? In truth, I know not". It would take his master two more years to present his first formal statements on the question in a Relectio (I537) entitled De Temperantia (On Moderation). It was in that conference that Vitoria first chose to tackle the thorny issue of the conquest of the Indies himself. As such, De Temperantia is essentially a prologue or introduction to his thoughts on the issue.

This conference was given in a politically complicated year for Charles V. It was the same year that Pope Paul III issued the bull Sublimis Deus (May, I537), in which the Holy Church declared that grave offences were being tolerated (slavery and forced conversion) under the rule and dominion of the (Holy) Roman Emperor. This was certainly a major warning sign for Charles V.

The wording of the papal bull was particularly clear: "Indians are truly men" and "not only capable of understanding the Catholic Faith but, according to our information, they desire exceedingly to receive it". For the Church, the Indians "are by no means to be deprived of their liberty or the possession of their property, even though they be outside the faith of Jesus Christ" notwithstanding "whatever may have been or may be said to the contrary". The papal document was precise: "they may and should, freely and legitimately, enjoy their liberty and the possession of their property; nor should they be in any way enslaved; should the contrary happen, it shall be null and have no effect".

By the time of that bull, the Emperor began requesting Francisco de Vitoria's counsel on certain theological issues. The ruler and the academic knew each other personally, since at least June 19, I534, when the former visited the University of Salamanca and attended the lectures of several professors. Earlier still, in September 7, 1530, Isabel of Portugal had written a letter to the University of Salamanca, requesting theological counsel on Henry VIII's (of England) controversial divorce from Catherine of

\footnotetext{
Ior) See Baciero, C. "Conclusiones definitivas de la segunda generación. Vitoria”, La Etica de la conquista de America, Corpus Hispanorum de Pace, Vol XXV; CSIC, I984, p. 4I6.
} 
Aragon, daughter of Ferdinand and Isabella of Spain and aunt to Charles V. The academic authorities of Salamanca selected Vitoria, together with Montemayor, to express their formal opinion (Parecer), which would later result in De Matrimonio, a Relectio delivered on January 25, I53I.

After that, Charles V wrote to the friar directly requesting a Parecer on the issue of "the education and conversion of the Indians to the holy faith". This letter is related to the papal bull Sublimis Deus, issued 20 months earlier, and marks the first time that a Bishop from the Indies, taking the bull seriously, posed that type of question to the Emperor. The letter was written in Toledo on January 3I, I539 and refers expressly to doubts raised by the Bishop of México, Juan de Zumárraga, to the Council of the Indies. ${ }^{102}$

By that time, Charles V was probably not aware that Francisco de Vitoria had already presented the first De Indis as a conference in Salamanca University, on January I, I539. The main theme of the Relectio was whether or not it is lawful to baptize the children of unbelievers against the wishes of their parents. Six months after that conference, on June I8, the friar would present the second De Indis arguing in favour of universal restrictions in the natural right to war.

Presenting those ideas to the most learned audience of his time (the university community) was a major display of audacity for a professor of the I6th century. The Emperor, being in questionable possession of the Indies and engaged in several wars in and around Europe as well as the New World, was severely irritated by these two conferences. In response, he wrote to the Prior of San Esteban expressing his consternation that members of his monastery were calling into question Spain's rights to the Indies. A letter dated November IO, I539 delivered an imperial warning:

I have been informed that some religious men of that house have put to discussion and treated in their sermons and in relectios, on our right to the Indies, Islands, and terra firma of the Ocean Sea... [I] charge and order that thereafter, without any delay, you call before you the said teachers and religious men... and obtain from them sworn affidavits that they declare at what times and places and before what persons they have discussed and affirmed the aforementioned.

102) See Real cédula del emperador Carlos V en que consulta al maestro fray Francisco de Vitoria sobre asuntos de Indias (Toledo, 3 I de enero de I539) in Esperabé de Arteaga, E., Historia pragmática e interna de la Universidad de Salamanca, vol.II, I9I7, p. 427. 
In addition, Charles $\mathrm{V}$ ordered the Prior to collect the manuscripts referring to these texts and send them to the Royal Court. Finally, and more importantly, he also forbade addressing such matters in public, without his "express permission". ${ }^{103}$

It may seem surprising that, soon after that, Charles $\mathrm{V}$ would continue to request the advice of the friar for the rest of his life. Reasonably, shifting from sticks to carrots (counsel) was a wise policy decision towards San Esteban: at that time, theology was the supreme science in Europe. Moreover, "theological hegemony" was unquestionably vested in Spain by the Chair of Theology in Salamanca. ${ }^{104}$

On April I8, I539, another imperial letter was sent, by Zumárraga's suggestion, requesting that Vitoria select twelve clergymen of good reputation

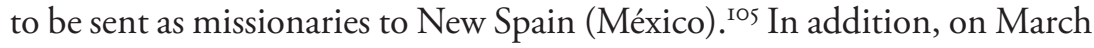
3I, I54I, Charles V formally requested (Real Cédula) that the friar formed a committee of theologians, under his tutelage, to make a judgement on the baptism of the Indians. ${ }^{106}$ As a result, on July I of that year, Vitoria and other eight theologians signed their Parecer recommending preliminary instruction before baptism. ${ }^{107}$ And there would be more consultations.

Significantly, at the end of his life, the Dominican was invited by Charles $\mathrm{V}$ to assist as Imperial Theologian to the Council of Trent (I545-I563). Due to his advanced illness, he declined in a formal letter to the king and his son Phillip (April or May I545), expressing a preference for his disciple Domingo de Soto. Shortly after, Vitoria died on August I2 of I546, while the Council was still in its first round of sessions.

However, it is not only the individual contributions that matters but what the friar envisioned in academic terms; his impact on the status quo is also due to his decisive contribution to the creation of a powerful school

\footnotetext{
103) Getino, L.G. El Maestro Fr ... op. cit. p. I50.

104) Getino, L.G. El Maestro Fr ... op. cit. p. 67.

105) See Real cédula de Carlos V al maestro fray Francisco de Vitoria, en que le ruega escoja de entre sus discipulos doce sacerdotes de buena vida y doctrina para enviarlos a Nueva España (Toledo, I8 de abril de I539), in Beltrán de Heredia, V. Los manuscritos del Maestro Fray Francisco de Vitoria, O.P, I928, p. I63.

106) See Real cédula de Carlos Ven que consulta al maestro fray Francisco de Vitoria sobre asuntos de Indias (Madrid, 3 I de marzo de I54I) in Esperabé de Arteaga, E. Historia ... op. cit. p. 428. 107) See Parecer de los teólogos de la Universidad de Salamanca sobre el bautismo de los Indios, in Vitoria, F. Relectio de Indis, Corpus Hispanorum de Pace, Vol. V, CSIC, 1967, p. 158.
} 
of thought that not only influenced the development of disciplines such as political theory, legal philosophy and what later would be called international law, but also policy-making. In fact, the "School of Salamanca" is a perfect case study on the potential of schools of thought in the evolution of public policy. 24 of his disciples held chairs at Salamanca and around 5000 students passed through his lecture-rooms. ${ }^{108}$ Over the following decades his students, pupils, colleagues and successors disseminated several common ideas that influenced public decision-making both in Spain and the Indies. ${ }^{109}$

The School of Salamanca opened fronts in many 'battles' during its period of splendour. A particularly interesting example is the appearance of some of Vitoria's ideas in both the formal and informal negotiations of the Council of Trent. Astrain describes these sessions of intense debate closely connected to the project of the Salamanca School. From what he recalls, the Spanish theologians at Trent tenaciously defended the opinion that Bishops received their potestas directly from God, a so-called "divine right of Bishops".

What one commentator of that time described as a no more than an "obscure theological question" was in fact extremely important in political terms. In writing that these "theologians fought for their opinions as knights fight for their dames", ${ }^{\text {IIo }}$ Astrain also suggests that these thinkers were idealists removed from reality. However, this was certainly not the case; the Seconda Scolastica was perfectly aware of the political relevance of this non "obscure theological question" for the fate of their ideas concerning the education of the Amerindians: it must be remembered that many of the Bishops in America had connections with San Esteban, and paid some deference to the (moral) authority of the School.

But leaving this topic for further research aside, Vitoria also had great impact in the areas of European diplomacy and the formation of treaties. As Lesaffer explains, the many references to the Christian res publica found in the preambles of European peace treaties of the age indicate that the Christian princes considered themselves to be responsible for the welfare, not only of their own territories and subjects "but of the whole of Christianity".

\footnotetext{
108) Hamilton, B. Political Thought in ... op. cit. p. I75.

109) For a detailed list of professors and students from Salamanca in the Indies (I534-1585) see Pereńa, L. La Escuela de Salamanca. Proceso a la Conquista de America, Salamanca, I986, pp. 216-255.

Iro) Astrain, A. "Los españoles en el Concilio de Trento", Razón y Fe, IV, p. 319.
} 
Vitoria is among the first thinkers who showed a concern for this bonum commune of the whole world. As Lesaffer points out, the sovereign princes were the highest secular authorities within the Totus Orbis: "By consequence, they were expected not only to enforce their own interests and rights under the ius gentium, but also to enforce the law of nations within the Totus Orbis in general". Thus, in the preambles to the peace treaties, the princes declared themselves to be responsible for the highest goals of Christianity as a whole". ${ }^{. I I}$

In regards to the Amerindians, the School's concerns on the affairs of Indies influenced policy formation and helped to give a humane dimension to the legal instruments of dominion. Their critical voice in the Old World, together with that of the Orders in the New World influenced policy design and the enactment of legislation. Three years after De Indis, and six years before Vitoria's death, a Junta was convened by Charles V to promulgate the New Laws of Indies (I542). According to Pagden, the "changing tone" of this legislation regulating the Crown's relationship with both the colonialists and the Indians, and "the numerous, if ultimately ineffective attempts to curb the activities to prevent further atrocities", suggests that the Salamanca theologians "voiced their views to some effect in the influential circles where they moved". ${ }^{\text {II2 }}$ Certainly, it had more than some effect. That legislation would simply not have come about without the formal constructions of those men.

In consequence, half a century after Columbus reached La Española, the controversy was growing among those who were aware of the affairs of Indies and thus accurate fact determination was becoming a major concern. ${ }^{\mathrm{II}} \mathrm{In}$ fact, Charles V decided to arrange a series of debates at the Royal Court of Valladolid in 1550 and I55I between Juan Ginés de Sepulveda, who backed the status quo and Bartolomé de Las Casas, who pleaded for change. ${ }^{\text {II } 4}$ The final objective of those debates was to clarify several major issues concerning

III) Lesaffer, R. "Peace treaties from Lodi to Westphalia". Peace Treaties and International law in European History, Cambridge University Press, 2004, pp. 32-33 (emphasis added).

II2) Pagden, A. Spanish Imperialism and the political imagination. Studies in European and Spanish-American Social and Political Theory I5I3-I830, Yale University Press, I990, p. 25.

iз3) Hernandez, R. “The internationalization ... op. cit. IO44.

II4) Abril-Castelló, V. "La bipolarización Sepúlveda-Las Casas y sus consecuencias: la revolución de la duodécima réplica”, La ética de la conquista de América, CSIC, 1984, pp. 229-288 
the Amerindians. Vitoria's disciple de Soto played a part in this politically sensitive contest as one of the theologians in charge of compiling the official summary of the discussions.

In the meantime, while the State apparatus was searching for answers, the encomenderos and their social networks were already challenging the New Laws of Burgos with civil disobedience, revolts, armed opposition and killings of public representatives in the Indies. In the end, Charles V was more compelled by these events than by the arguments of theologians, public officials and missionaries such as Jacobo de Tastera, Zumárraga (first Bishop of México) or Marroquín (first Bishop of Guatemala), among others. As a result, a weaker version of the New Laws was issued in 1552 .

The experience of the Spanish in the Indies affected later conquests by other groups and nations, beginning with North America. Several aspects of the Spanish project of evangelization and conquest, as well as the arguments and legal titles challenging the Conquest, were replicated for the British colony of Virginia. In the words of Elliot, the same "providential mission" was pursued. In fact, the Pamphlet for the Virginia Enterprise written by the elder Richard Hakluyt reads as follows: "we may, if we will proceed with extremity, conquer, fortify, and plant in soils most sweet, most pleasant, most strong, and most fertile, and in the end bring them all in subjection and to civility". ${ }^{\mathrm{II}}$

Thus, the 1606 charter of a joint-stock company (The Virginia Company) and the "contract" of Cristobal Colón with Isabella and Ferdinand (Las Capitulaciones) ${ }^{\mathrm{I} 6}$ share a similar evangelizing component. In the words of Richard Hakluyt in his Discourse of Western Planting (1585), "Now the King and Queens of England have the name of Defenders of the faith; by which title I think they are not only charged to maintain and patronize the faith of Christ, but also to enlarge and advance the same". ${ }^{177}$ William Crashaw argued

II5) Elliot, J.H. Empires of the Atlantic World: Britain and Spain in America 1492-1830, Yale University Press, 2006, p. II and 35 .

i16) See Pérez-Prendes, J.M. “Los criterios jurídicos de Cristóbal Colón”, Congreso de Historia del descubrimiento (I492-I556), Actas de la Real Academia de la Historia, III, I992, pp. 450480 and Pérez-Prendes, J.M. "Sobre la naturaleza jurídica de las llamadas capitulaciones de Santa Fe", El reino de Granada y el nuevo mundo, Diputación Provincial de Granada, 1994, pp. $45-59$.

I17) On the promotional role of the two Richard Hakluyts see Schmidt Horning, S. "The Power of Image: Promotional Literature and Its Changing Role in the Settlement of Early 
the same idea in a sermon of I6ro before the Virginia Company, clearly borrowing from Vitoria the idea of a universal right conferred by the law of peoples to freedom of trade and communication (ius communicationis). ${ }^{\mathrm{II} 8}$

Thus certain elements of cultural analogy and normative transplant in relation to Spain are present in the conquest of America; and a critical intellectual replication is evident as well. In the words of Robert Gray, the Chaplain to the Virginia Company, in his pamphlet $A$ Good Speed to Virginia (I609):

by what right or warrant can we enter into the lands of these savages, take away their rightful inheritance from them, and plant ourselves in their places being unwronged or unprovoked by them? ${ }^{119}$

In conclusion, Vitoria and his colleagues, along with critical missionaries in the Indies, had some impact on other cases of evangelization and conquest. In fact, it could not reasonably have been otherwise: human beings tend to approach social interaction by analogy almost intuitively, considering previous models and patterns of behaviour. In short, any initial socialization between peoples tends to be based primarily on precedent.

\section{Progress and the Legal Mind}

Moving beyond the intellectual frontier of the Old World, the modes of conventional thinking had to be abandoned. Naturally then, these men of moral and religious conviction were not free of doubts, vagueness and self-contradiction, as their texts evidence. However, this process of formal "doubting" or questioning is the most important intellectual contribution to progress, especially in the questioning of the world-wide exercise of power through the (de)legitimizing vehicle of theology. From this questioning of power, a conception was developed to deal with an unexpected New World: universalism.

The blackfriar also deserves credit for two other major contributions. First, his ideas contributed to a shift in the direction of the policies of the European Empire of Charles V, a unique power structure that, together with the Holy

Carolina”, 70 North Carolina Historical Review 4 (1993): 365-400.

in8) Elliott, J.H. Empires of the Atlantic World ... op. cit. p. 49.

Iig) Elliott, J.H. Empires of the Atlantic World ... op. cit. p. 4I. 
Church, had nurtured aspirations towards unlimited expansion. Vitoria's universalist ideas ultimately refuted the claims to universal jurisdiction of both the Emperor and the Pope. Secondly, and directly connected to this, his ideas put powerful concepts into circulation that would help others to conceive of an alternative legal world within a single secular and consensual framework. This idea slowly began to take shape and develop through the initial systematizations of legal thinkers such as Grotius, Gentili and others.

Francisco de Vitoria, being a friar and a theologian of the I6th century, could hardly have avoided applying the cultural parameters and values of Western (Christian) civilization to the Amerindians. ${ }^{\text {I20 }}$ Thus, paraphrasing Cavallar, Vitoria's moral cosmopolitanism, while incomplete, was still an impressive feat. ${ }^{\text {I2I }}$ The Dominican was cleaving a wedge into conventional thinking not only with new ideas but doubts and questions. His rational questioning exemplifies a subtle and important shift in the evolution of modern thought. In this regard, the formalization of such doubts is a clear manifestation of Renaissance thinking; the age of reason was dawning and rationalism was on the rise.

The geographical and social reality of the American Indies posed an urgent quaestio facti and quaestio iuris that would help to unlock the door to modernity. Many arguments in Vitoria's lectios and relectios discuss grounds that might provide legal justification for one thing or another. In his texts, he rejected some while accepting others with caution and reservation. Even legal titles such as those concerning the tutelage of the Amerindians were, in his own words, mentioned for the sake of the argument but not asserted with confidence. In sum, the emergence of doubts and their interaction with facts (versus beliefs) is one of the important steps towards modernity. Partly because of this, the ideas of the blackfriar have been the object of an enormous amount of secondary literature.

The study of his philosophy poses critical questions from both an epistemological and historical standpoint in turn. To start with, Vitoria was a man of Scholastic thought, certainly of a renovated variety but, nonetheless, a mode of thinking within structural constraints. Under the overarching

\footnotetext{
120) For both the protestant and "Norman Yoke" discourse on the American Indians see Williams, R.A. The American Indian in Western Legal Thought. The Discourses of Conquest, Oxford University Press, 1992 (parts II and III).

I2I) Cavallar, G. "Vitoria, Grotius, ... op. cit. p. 188.
} 
territories as well. Certainly, Isabel of Castile had an interest in interpreting the bull the second way. As she stated clearly in her Codicilio, she had obtained dominion.

The legal elites attendant on the Crown used a clear line of argument to legitimate the king's dominion of the New World: the Pope, by his Plenitudo Potestatis had granted the lands of the "barbarians" to the Crown of Castile. However, for Vitoria, papal bulls did not constitute solid legal grounding. The friar was probably not ignorant of the fact that members of the Roman Curia were all too familiar with the practice of selling political favours, in the same manner as those electors who had granted Charles V the title of Holy Roman Emperor (thanks to the letters of credit from the Fugger bankers). ${ }^{122}$

Francisco de Vitoria's main arguments challenging the supreme power of the Pope in the Indies are as follows: I) the Pope has no universal dominium by natural, divine law, or human law; 2) even if he had such a dominium, he could not transfer it to a secular power; 3) the Pope's temporal power is restricted to purely spiritual matters; and 4) the Pope has no temporal power over the Indians. In short, Vitoria rejected, in the first two Relectios, the claim that the Pope has temporal jurisdiction above all princes, and declared, in his fifth Relectio, that the Pope was not the temporal master of the world.

Yet the idea of "Empire" was very appealing to some of the most powerful families (dynasties) controlling Old Europe. For the Habsburg, the Valois, and other dynastic European families, the expansion of the Roman Empire and the imperial coronation of Charlemagne (8oo) had nurtured a dream of power and dominion. However, it was the Habsburg dynasty that won the greatest prize of all: the Monarchia Universalis. According to Lesaffer, "Charles V may have been the last emperor to be able to aspire to secular supremacy over the other 'sovereign' princes". ${ }^{123}$

The monarch had managed to be appointed successor to the Roman Caesars and thus, the secular leader of Christianity. The legal basis for this grand plan could only be gradually de-legitimized by institutions such as university faculties. Francisco de Vitoria was among those professors who publicly opposed that unlimited concentration of power. His conference

\footnotetext{
122) For a detailed study of the relationship of Charles $\mathrm{V}$ with the financial community see Carande, R. Carlos Vy sus Banqueros (3 volumes), Crítica, 1990.

I23) Lesaffer, R., "Peace treaties ... op. cit. p. 32.
} 
entitled De potestate civili (I528) is particularly direct in this regard. But it is a letter to a friend of his that best captures his strict position in regard to unchecked power: "To the King ... Don Fernando was called simply "Your Mercy"; but now is called "Your Majesty" and "Holy Caesar"; nothing remains but to say he is God". ${ }^{124}$

In considering the limits of public power, Francisco de Vitoria admitted several forms of dominion (dominium) valid to its legitimate exercise: unde illa distinctio iuristarum, dominium altum bassum, directum utile, merum mixtum. But while accepting those I) high, 2) low, 3) direct, 4) useful, 5) pure (merum) and 6) mixed dominions, the blackfriar rejected that Charles $\mathrm{V}$ was Emperor of the All the World: imperator non est dominus totius orbis. And, even if Charles V were indeed Emperor of All the World (dato quod imperator esset...), he could not in any case abrogate private property rights.

These positions certainly constitute an intellectual public challenge. They gave shape to potentially dangerous ideas for the status quo. In consequence, the censoring of these ideas, so explicitly mandated in an imperial letter to the prior of San Esteban (I539), would be strongly enforced by the state apparatus and the power elites of the Court. As a result, the Relectios of Francisco de Vitoria would have to wait to see the light of day in print until Charles V had died and, even then, the first edition had to be printed in France. Thus the first edition of his conferences came to light in Lyon (I557) at the publishing house of Jacques Boyer. After that, there was a succession of editions disseminated all around Europe, in Salamanca (1565), Lyon (fourth edition, I587), Antwerp (I604), Venice (I626), Salamanca (I680), Cologne (I696), Madrid (I765), etc.

The prohibition against publication, in the end, had not been able to contain the spread of those ideas but only to slow it down. In fact, the ideas were widely disseminated by spoken word and transcripts. Although Charles V had tried to inhibit this, he lacked the means to prevent informal communications and relationships (decentralized dissemination of manuscript copies by his disciples and students). The classroom had provided the blackfriar with a uniquely powerful channel of communication with the future elites of Spain, many of whom were educated in the University of Salamanca and had informal access to those ideas. As a result, the political importance of these Relectios in de-legitimizing the status quo was clear.

I24) See Vitoria, F. Comentarios a la Secunda secundae ... op. cit. 
The power elites made efforts to contain the impact of De Indis; from the original prohibition to express those ideas in public by formal letter of Charles $\mathrm{V}$ to the later process to include Vitoria's works in the Index of Forbidden Books by Pope Sixtus V (I590). ${ }^{\mathrm{I} 25}$ But there was a more subtle action taken that deserves to be mentioned: the authenticity (/authorship) of the words attributed to the blackfriar was formally questioned by Francisco de la Peña (I608), a member of the faculty of Law at Bologne and also of the Sacred Tribunal of the Roman Rota, as there was no 'official' published version of De Indis. ${ }^{\mathrm{I} 6}$

\section{A Religious Moderate}

The Flemish humanist Nicolaus Clenardus (Cleynaerts), a professor of Greek at the University of Salamanca from I53I to I537, offers us a good portrait of Francisco de Vitoria. In his collected correspondence, published in Antwerpen (I566), Cleynaerts describes the admiration that Vitoria enjoyed among his academic peers. In one of these letters, from I534, Cleynaerts writes to Johannes Vaseus about Vitoria: "[a man] of admirable simplicity; he has a singular love for scholars...You may not easily glean all of his qualities, because his erudition is quite vast, and yet, he does not glory in it". Vaseus agreed, describing Vitoria as a man of "incredible erudition and almost unlimited reading", concluding with this reflection: "this would he have left in evidence, had he been as zealous to write as he was capable of extraordinary mastery to do so" (I540-I54I). And one last appraisal deserves repeating here:

The fame of his erudition is great in France and Spain ... I know no one, even among those who have spent their life writing in Latin, whose letters have given me so much pleasure as the many [I have] received from Vitoria. If one day, he finally decides to write, this man's fame will encompass the scholarly world. Salamanca is ignorant of the treasure she has in our Vitoria. ${ }^{\mathrm{I2}}$

\footnotetext{
125) Godman, P. The Saint as Censor: Robert Bellarmine between Inquisition and Index, BRILL, 2000, pp. 136-I38.

I26) Vitoria, F, Relectio de iure belli o paz dinámica: escuela española de la paz, primera generación I526-I560, Edition by Luciano Pereńa Ed, CSIC, I98I, p. 82.

127) Roersch, A. La Correspondence de Nicolas Clenard, Palais des Académies, I94O-I94I, vol.I, p. 38 , p. 133 and pp. 225-226.
} 
Being such a respected intellectual figure, it is puzzling that he never published his work, except for some prefaces from his early years in Paris. The blackfriar certainly had nothing against publishing. In fact, he actively participated in procuring one of the first university presses in Spain, and many of his disciples did publish their works during his lifetime. We can only guess that Vitoria was simply dedicated exclusively to his teaching, a vocation that he performed with outstanding success. According to Melchor Cano, "Master Vitoria may have disciples wiser than he, but ten of the most learned cannot teach like him"; or even in the friar's own words, "Master Astudillo knows more than I, but he cannot sell it as well as I can." 28

The friar's was a unique academically driven personality. Characterized by hard work and austerity, this disposition appears to have been formed in his early years as a student and professor in Paris. In a preface to the works of Peter Crockart, in I5I4, Vitoria reveals his devotion to the academic life: "after many years spent in writing, in teaching, in debating, when by surplus of rights you could have chosen a more restful life". ${ }^{29}$ This praise for Crockart would be fitting to his own later life. In fact, on several occasions, his health broke down from working so hard that his superiors had to make special accommodations for his classes due to his deteriorating health. A remarkable illustration of both his devotion for teaching and his students' devotion to him is the fact that in his last days, due to illness, he was carried from San Esteban to the university lecture rooms on his students' shoulders.

Besides being a man committed to academia, he was an example of moderation for his time. He taught the value of moderation to his pupils and disciples and even expounded on its importance in a Relectio under the title, On Moderation (De Temperantia). The conference, concerned in part with the affairs of the Indies, was presented to the academic community two years before De Indis (I539). As a direct result of his personal advocacy for intellectual temperance, this has been one of the underlying values permeating the work of the School of Salamanca.

Melchor Cano expressly refers to the learned friar as "a moderate" in his masterpiece on the ten sources of theological proof: "vir erat ille natura ipsa moderatus". In this contribution to theological positivism, De Locis Theologicis Libri XII (IS63), Cano reflected on the need to limit the weight

\footnotetext{
128) Getino, L.G. El Maestro Fr ... op. cit., p. 66.

129) Getino, L.G. El Maestro Fr ... op. cit., p. 3 I.
} 
that authority is given in academic thought. To support this point, Cano, who became the Chair of Theology after the death of Vitoria, recalled that his Master (Vitoria) taught his disciples not to take Thomas Aquinas' own words at face value without proper analysis: "and though he was a man of moderate character, he at times dissented from Thomas Aquinas, and garnered greater praise in his dissenting than in consenting."

However, the process of unlocking the gates to modernity would not be easy. It was precisely at the time that Vitoria obtained the Chair of Theology in 1526 that some of Erasmus' ideas were being publicly challenged in Spain. At that time, he was required to participate in the Junta of Valladolid (I527), a conference for theologians with the purpose of assessing the acceptability of the Erasmus's ideas. The meeting was convened by the General Inquisitor Alonso Manrique, an Erasmist himself. Particularly interested in having Vitoria present at the Junta, he asked the university authorities that they allow Vitoria to attend "for some days, which will not be many" (May 22, I527). The sessions took place from June to August of I527 with the purpose of discussing "some matters touching on service to God and the welfare of our holy Catholic faith ". ${ }^{30}$

Notwithstanding the secrecy of the proceedings, the Dutch humanist and his circle received many clues about who was saying what in these sessions, thanks to the group of Erasmist professors participating in the Junta. As the conference was a major concern for Erasmus and his supporters, they followed the proceedings with keen attention and lobbied to avoid a negative determination, an interesting example of early intellectual diplomacy. The first reference to Vitoria to appear in the correspondence of the Erasmists was in a letter from the humanist Luis Vives to Erasmus himself, explaining that the blackfriar would have a sympathetic position toward his texts (June I3, I527). In that letter, the author of Adversus pseudodialecticos compared Vitoria's character with that of his brother (Diego de Vitoria), who also participated in the sessions:

Diego has a brother quite different from him, Francisco de Vitoria, who is also a Dominican, and a theologian in Paris. He is an individual of the greatest renown and esteem amongst his brothers. Remember that on more than one occasion he defended your cause before different conferences of theologians in Paris. He is very skilful in these scholarly arguments.

I30) Getino, L.G. El Maestro Fr ... op. cit., p. 92 and I05. 
During his early years as student in Paris, Francisco de Vitoria had had regular contact with Vives as well as exposure to the ideas of Erasmus and his circle of friends and supporters. ${ }^{13 \mathrm{I}}$ To reassure Erasmus about the high esteem that Vitoria held towards him, Vives added, "he admires and adores you". ${ }^{132}$ Thus, Erasmus decided to send a letter to Vitoria on November 29, of 1527 under this heading: Letter to a certain Spanish theologian from the Sorbonne.

The Dutch thinker's letter attempted to discover what position Vitoria would take in these sessions. Erasmus complained that the assembly was "examining in a scholastic and Sorbonnian way something of purely rhetorical value". However, he appealed to Vitoria's "dignity" and expressed the importance of the determination by writing, "the world expects something extraordinary of this Assembly of theologians". Finally, Erasmus added that in that regard the world would have more reason to thank the theologian than "Erasmus himself".

It is not clear when these words reached Vitoria. In any case, they would not have had much significance because the sessions were suspended due to an outbreak of plague in Valladolid. From what can be deduced from the letter, Erasmus was certain that Manrique intended to reopen the sessions in the future. In the end, however, this did not happen; we can only guess what would have resulted from the proceedings had they continued. Bataillon has noted that Juan Maldonado, in a letter to Erasmus, referred to a friar whom he did not name, a very wise Dominican who had played a major role in the assembly, and of whom he complained since sometimes the said friar had deemed that the works of Erasmus would benefit from the deletion of certain lines, and yet other lines he would condemn to the fire. For Bataillon, the Dominican in question was in all probability Vitoria. ${ }^{133}$

There are several transcripts of what Vitoria said in those sessions. The following are his conclusions on those statements of Erasmus which he was required to review:

\footnotetext{
131) Villoslada, R. La Universidad de Paris durante los estudios de Francisco de Vitoria, Universidad Gregoriana, Rome, 1938.

132) Vives, J.L. Epistolario (José Jiménez Delgado Ed), Editora Nacional, I978, p. 466.

133) Bataillon, M. Erasmo y España. Estudios sobre la historia espiritual del Siglo XVI, Madrid, I979, p. 274.
} 
It is quite possible that all those sayings for which Erasmus is reproached were understood by him in the most catholic [general] sense; and this may be believed. But nothing good can be expected from them for the consolidation of the faith ... and it is imperative that such matters be prevented from spreading by word of mouth, which cannot be done but by suppressing those sayings of Erasmus and others like them ... and I believe Erasmus himself will not take it badly that I said so. ${ }^{134}$

Conscious of his own auctoritas as the newly elected Chair of Theology at Salamanca, Vitoria expressed himself with caution and moderation. ${ }^{135}$ This attitude is particularly praiseworthy in an academic that had certainly read Erasmus' mocking opinions on theology (the method) and theologians (the men): for most of the Erasmists, paraphrasing Rico, the theological method was "an idol to be demolished". ${ }^{136}$ In fact, Erasmus' assertions on theology and theologians were vitriolic from the first word of chapter 53 in Stultitiae laus (In Praise of Joy, I5II), a book conceived in 1509 while he was a guest in the home of his friend Thomas More:

Then there are the theologians, a remarkably supercilious and touchy lot. I might perhaps do better to pass over them in silence without "stirring the mud of Camarina" or grasping that noxious plant, lest they marshal their forces for an attack with innumerable conclusions and force me to eat my words.

To paraphrase Bernice Hamilton, the tendency of the School of Salamanca was, "to try and incorporate Renaissance scholarship into a Scholastic framework", unlike the followers of Erasmus, "who wished to abolish the scholastic method altogether" ${ }^{137}$ In consequence, the theologians invited to participate in the sessions by the Erasmist Manrique were not only critical with the substantive content of works such as Erasmus's Enchiridion but also demanding due respect from this humanist. The Dutchman had mocked their entire academic world, and so they probably considered these sessions as an opportunity to send a message across the table to the Erasmists.

134) Bataillon, M. Erasmo y España ... op. cit., p. 255 (emphasis added).

135) In fact, he made a more severe judgement in his classes. See Beltrán de Heredia, V. Los manuscritos ... op. cit. p. 43.

136) Rico, F. El Sueño del Humanismo: De Petrarca a Erasmo, Alianza, 1993, p. II8.

137) Hamilton, B. Political Thought ... op. cit. p. I74. 


\section{The Man in Context}

Francisco de Vitoria was a theologian concerned with finding answers to the urgent questions of his time. In order to do so, the blackfriar had to confront and clarify some of his intellectual doubts on the one hand, and to question certain elements of the status quo, on the other. This probing spirit, for a man who was born in the time of the Reconquista of Al-Andalus, raised in the culture of the Catholic Kings, attached to a religious order (Ordo Praedicatorum), and trained as a theologian in the old scholastic tradition, is indeed remarkable. For this reason, his intellectual biography is a perfect case study on the limits and conditions of academic development in the transition to modernity. ${ }^{\mathrm{I} 3} 8$

A significant portion of early contemporary studies on Francisco de Vitoria has focused on the international legal aspects of his thinking. Unfortunately, this has too often been done by simply adapting doctrines of the past to present day categories of international law. ${ }^{139}$ According to Pagden, "by re-describing the battles of the early modern terms, by making Francisco de Vitoria the remote ancestor of the Charter of the United Nations or the Bill of Rights, the specificity of the conflict is lost, and with it the possibility of its significance as a process over time". ${ }^{140}$ As a result, for example, some contemporary literature on the subject attributes to the friar the doctrinal origins of the United Nations, ${ }^{\mathrm{I}}{ }^{\mathrm{I}}$ some depicts him as a figure of economic liberalism, ${ }^{\mathrm{I}}{ }^{2}$ and some links his ius communicationis with the regulation of telecommunications satellites. ${ }^{\text {I43 }}$

Obviously, there is a risk of de-contextualization when classifying circumstances of the past under concepts and measures pertaining to the modern

138) For a characterization of the friar as a "traditional intellectual in the gramscian sense" see Barbier, M. "La notion de respublica chez Vitoria", Aspects de la pensée médiévale ... pp. IOO-IOI.

139) See particularly Pérez Luño, A.E. La polémica ... op. cit., p. 3 I.

140) Pagden, A. The Uncertainties of Empire: Essays in Iberian and Ibero-American History, Aldershot, 1944, p. x.

141) Hernandez, R. Un español en la ONU. Francisco de Vitoria, I977.

142) Urdanoz, T. "Síntesis teológico-jurídica de la doctrina de Vitoria”, Corpus Hispanorum de Pace, Vol.V, CSIC, 1967, pp. XLIII-CXLII.

I43) Desantes, J.M. "El jius communicationis según Vitoria y la regulación de los satélites de difusión directa”, 7 Atlántida 47 (I970): 47I-489. 
legal culture. However, some of those early contemporary efforts have drawn attention to the blackfriar in present academic literature. As a result, there is a healthy amount of work being done today on Vitoria. At this stage, we may push forward to understand not only his contributions but also to trace the development of contemporary modes of thinking embodied in his texts (i.e: internal coherence, logical deduction, etc).

However, in order to do so, it is necessary to highlight and expose, rather than minimize or suppress, some of the inner contradictions in Vitorias's thinking. In this regard, there has been a certain over-emphasis on the cutting edge character of his ideas. Just one example is his position on the treatment of black Africans in comparison with that of the American Indians. Although he clearly expressed his indignation with regard to the treatment of the Indians, Vitoria had no objections with respect to the Portuguese African slave trade. In a private letter of 1546 to Bernardino de Piqué (with I8 March as probable date), Vitoria writes: "if [the Africans] were treated humanely, they would be better off as slaves under the Christians, than being free in their own lands". ${ }^{144}$

Evidence such as the letter mentioned above has led the historian Pagden to hold that Vitoria "was far from being the 'humanist' that many historians have attempted to make of him". ${ }^{45}$ But what then was the blackfriar really: a humanist of lower 'quality' or 'rank'? It is ultimately of little value to 'grade' the intellectual performance of a thinker according to the mould of a cultural canon. Vitoria was certainly a humanist thinker. However, the nucleus of his philosophy lies at the intersection of the Doctrinal tradition of the Middle Ages and the budding phenomenon of Humanism. In consequence, we should expect to find dissonances in his work, as his ideas were formed by two ways of conceiving the world, spanning old sources of authority and new conceptions, as well as developing mediations between the two. In sum, the richness of his social reality does not fit a single cultural mould. Francisco de Vitoria gave form to his ideas within a vibrant cultural acquis that mixed humanism with the intellectual legacy of the Middle Ages.

I44) Beltrán de Heredia, V “Carta de Fray Francisco de Vitoria al padre Fray Bernardino de Vique, Colección de dictámenes inéditos”, 43 Ciencia Tomista (I93I): 173-I74.

145) Pagden, A. The fall of natural man ... op. cit., p. 60. 
One of the friar's major intellectual contributions was applying reason and imagination to the wealth of both classical and Christian culture. ${ }^{146}$ From that rich combination he tackled several major issues while cutting through the limits of the conventional thinking of his era, the geographic borders of his political community and the legal prerogatives of the European power structures of his time. With that kind of intellectual intensity, Vitoria reflects that Spain obsessed with personal dignity and a zeal for the Absolute so accurately portrayed by De los Rios. ${ }^{147}$ It is this characteristic posture that gave rise to the Seconda Scolastica of the Spanish golden age, which was essentially a group of men searching for answers to some of the great questions and problems of their time by reengineering the authoritative source of the status quo: theology.

Vitoria and his disciples were necessarily children of two modes of conception, faith and reason, in search of a compromise, however complex; besides being scholars, they were members of an Order (Ordo Praedicatorum) devoted to preaching the gospel around the world. Although the Dominicans were among the more advanced religious organizations of his time, they were nevertheless part of a religious order, which, by definition, pays tribute to a predetermined something/someone, a (revealed) 'truth', a god, as opposed to knowledge and reason. However, in spite of this limitation, many conceptions that would be instrumental to the future improvement of social life, or "progress", can be traced back to their texts and lectures.

"Progress" itself was beginning to take form as an idea both inside and outside of academia in the I6th century. In the words of the historian Maravall: "the doctrines of the men of the Enlightenment, in the I8th century, did not arise suddenly, without antecedents, but rather, conditioned by economic and social circumstances, respond to a long process, sometimes centuries long, and make use of theoretical elements from long before in their construction" ${ }^{148}$ The road towards the Enlightenment was being paved in Spain in the I6th century by such works as Cristóbal de Villalón's Ingeniosa comparación de lo antiguo con lo presente (I539) and Pedro Mexía's Silva de

\footnotetext{
146) Truyol, A. Historia ... op. cit., p. 80.

147) De los Rios, F. "Religión y Estado en la España del Siglo XVI (1926)", Obras Completas, Volumen II, Anthropos, I997, p. 484.

148) Maravall, J.A. Antiguos y Modernos: La idea de progreso en el desarrollo inicial de una sociedad, Sociedad de Estudios y Publicaciones, 1966, p. 6II.
} 
varia Lección (I540 ${ }^{149}$ among many others including the theologians from Salamanca.

As Fernando de los Rios pointed out in his 1927 conferences at Columbia University, the battle between Catholicism and Protestantism (and its concomitant religious wars) impinged severely on the objectivity of the writing of European history. ${ }^{150}$ In fact, Francisco de Vitoria almost vanishes from the history of ideas for three centuries due to the distorting effect in academia of the wars of religion, as well as the notorious practices of Empire and the resulting black legend about Spain. Fortunately, his memory has been recovered thanks to the seminal works of the Belgian Ernest Nys (I85I1920) and the American James Brown Scott (I866-I943), among others. In any case, while there have been great advances in the historical treatment of his ideas and his school, many interesting issues merit further research.

One of them is certainly the controversy over the contribution of Spanish Scholasticism to the collective construction of human rights. It stands to reason that making connections between the School of Salamanca and human rights is a matter of controversy; "human rights" is one of the 'crown jewels' of modern legal theory. However, it is clear that several of the master-values of European civilization that underlie the ideas of such thinkers as Vitoria and other theologians did have extensive impact on the slow, collective formation of the doctrine of human rights; these include: I) the unity of mankind, 2) the dignity of all men, and 3) equality among people.

It is difficult to imagine how those values, derived from basic cultural and religious postulates, could be denied a position in the history of human rights. This cultural and religious acquis nurtured the theological idea of natural law and thus paved the way for the development of the doctrine of human rights in the following centuries. Thus, the contribution of Vitoria and his disciples to the formation of the doctrine of human rights is embedded in that acquis and derives from natural legal thought. The original doctrines of these influential theologians, and other contemporary and later European thinkers up to the 17 th century, would pave the way for the progressive rationalization in the $\mathrm{I} 8 \mathrm{th}$ century, the formalization in the

\footnotetext{
I49) Mexía, P. Silva de varia lección. Ed. Bibliófilos Españoles, vol.I, I933-I934, p. IIO.

150) De los Rios, F. "Religión y Estado en la España del Siglo XVI (1926)", Obras Completas, Volumen II, Anthropos, 1997, p. 485.
} 
I9th century, and finally the legalization in the 2oth century of the idea of human rights.

\section{Critical Interpretations}

Two centuries after Charles V adopted the motto Plus Ultra (I516), foreshadowing the extension of his rule beyond the 'pillars of Hercules' (Gibraltar) to the New World, Giovanni Battista Tiepolo painted The Apotheosis of Spain (I764) on the ceiling of the Throne Room at the Royal Palace in Madrid. ${ }^{\text {III }}$ The fresco allegorically depicts the Spanish monarchy as a voluptuous woman with the 'pillars of Hercules' on one side and a hooded man on the other, along with other elements including Moors and Indians. The painting ostensibly celebrates the glory of Spain.

Almost two centuries later, the ceiling of one of the Halls of the Palace des Nations (Geneva) was painted by Jose María Sert with a decidedly different take: The Lesson of Salamanca (1935-1936). The mural basically depicts five colossi (the five continents) uniting their hands. On one side of the mural, the blackfriar and other professors are in discussion surrounded by attentive and studious disciples. In the classic Spanish tradition of burlesque, the composition includes a considerable number of donkeys standing amongst the scholars, by which we are meant to understand that some did not adequately grasp the lesson.

This later mural was unveiled in October 1936, three months after the Spanish Civil War had begun in prelude to World War II. After the nightmare of that world war and the fall of fascism in most parts of Europe except Spain, a radical revamping of the institutional structures of international law was invoked. At that moment, the idea of a world political community with common rules for all shone brightly as a necessary collective project for a post-war world (i.e: rules on the use of force). As a result, the figure of Francisco de Vitoria became both a moral and political point of reference for a whole new generation of men called on to construct a new international legal order.

After some quasi-hagiographic studies during that time, the blackfriar finally entered into the realm of standard historical analysis. The work of

\footnotetext{
I5I) See i.e, Rosenthal, E. "Plus ultra, non plus ultra, and the Columnar Device of Emperor Charles V" 34 Journal of the Warburg and Courtauld Institutes (I97I): 204-228.
} 
international legal historians such as Antonio Truyol y Serra (1913-2003) deserves mention in this regard. However, although the period of hagiographic eulogies is over, the standardization of historiographical approaches to the study of Vitoria is still incomplete. In fact, there is a whole new trend of historical revisionism producing studies that frame Vitoria in a diametrically opposite vein to those previous exercises. In these studies, the blackfriar is used as the springboard for an 'alternative history of international law'; the idea behind this new interpretation is simple but rather stunning: Francisco de Vitoria is the first legitimizer of colonialism and a key intellectual figure behind the "colonial origins of international law".

This approach has been taken by several recent studies. Henry Mechoulan, for example, argues that all of Vitoria's arguments can be summarized in two imperatives: I) that the Spanish have exclusive title to the despoilment of Amerindian wealth and 2) the right and duty to see to the salvation of Amerindian souls. In the striking words of this author, the Dominican's "real genius" is the "art of camouflaging the justification of a fact-colonization- by appealing to "interhuman sociability". ${ }^{52}$

Other critical arguments on Vitoria can be found in the field of American Indian legal studies. For example, in his book The American Indian in Western Legal Thought, Richard Williams defines "Victoria" (sic) as "the first articulator of a European discourse of conquest founded on secularly rationalizable norms and values". In the opinion of this author, the blackfriar "justified the extension of Western power over the American Indians as an imperative of the European's vision of truth". ${ }^{153}$ However, it is easy to agree with Cavallar that the totalizing "Western legal discourse" assumed by Williams incurs in "the fallacy of another great narrative" by constructing "a meta-narrative of modern history". ${ }^{54}$

Many of these studies are connected with the literature of the so-called Third World Approaches to International Law (TWAIL). ${ }^{155}$ As Mutua points out, the raison d'etre of TWAIL takes form from, among other sources, a

\footnotetext{
I52) Mechoulan, H. "Vitoria, pére du droit international? ... op. cit., p. 25 (emphasis added). 153) Williams, R.A. The American Indian in Western Legal Thought ... op. cit. p. Io6 and 107. 154) See Cavallar, G. "Vitoria, Grotius ... op. cit. 207 (emphasis added).

155) Snyder, F.E. and Sathirathai, S. (eds), Third World Attitudes Towards International Law, Martinus Nijhoff, 1987.
} 
much quoted passage by Mohamed Bedjaoui: ${ }^{156}$ "classical international law ... consisted of a set of rules with a geographical bias (it was a European law), a religious-ethical aspiration (it was a Christian law), an economic motivation (it was a mercantilist law), and political aims (it was an imperialist law)". ${ }^{157}$ Under this rationale, international law is "premised on Europe as the centre, Christianity as the basis for civilization, capitalism as innate in humans, and imperialism as a necessity". ${ }^{158}$ The broad argument of these studies is that international law is an inherently imperialist construct which stretches from the i6th century to the present day.

The works of Antony Anghie are a good example of this post-modern narrative. This former student and research assistant of Christopher Weeramantry began writing on international law and colonialism in an article (The Heart of my home, 1993) that resulted from their participation in the Nauru Commission of Inquiry (1986): ${ }^{159}$

Colonialism ... reproduces itself through its victims and continuously creates and represses new subjects. In this way, colonialism is like sovereignty itself. This is a challenge for international lawyers, whose craft inevitably demands the articulation and reproduction of the language of sovereignty and with it, perhaps, the suppressions and exclusions that characterize its history. ${ }^{160}$

Searching for a strong thesis, as candidate for S.J.D. at that time, he was perhaps over-reaching in his use of the old friar's texts: "Vitoria's work illustrates the centrality of the colonial encounter for the formation of international law and its key doctrines, showing the ways in which international law characterizes, excludes and disciplines peoples and societies understood as

156) Mutua, M. "What is TWAIL?", 94 American Society of International Law Proceedings 3I, April (2000): 3I-40.

I57) Bedjaoui, M. "Poverty of the international order", International law: A Contemporary Perspective, R. Falk, F. Kratochwil and S. Mendlovitz Eds, 1985, p. I53 (emphasis added).

158) See Mutua, M. "What is ...op. cit. p. 33 (emphasis added). For the so-called "post-colonial scholarship" and its foundational literature see, in particular, Said, E. Orientalism, Pantheon Books, 1978 and Said, E. Culture and Imperialism, Knopf, 1993.

159) Weeramantry, Ch and Berman, N. “The Grotius Lecture Series”, I4 American University International Law Review (1999): 1565.

160) Anghie, A. "The Heart of my Home: Colonialism, Environmental Damage, and the Nauru Case", 34 Harvard International Law Journal (1993): 445-506 (505-506). 
different and alien" ${ }^{16 r}$ Starting as the subject of an article on the "colonial origins of international law", ${ }^{162}$ the blackfriar became the key intellectual figure in a full monograph on the issue entitled Imperialism, Sovereignty and the Making of International Law, with that original article as its first chapter and theoretical foundation:

Despite Vitoria's significance as the first international legal jurist, the importance of his work has not been generally recognized as outlining, in clear and stark terms, the colonial origins of international law. ${ }^{163}$

The central idea of the book is that both the invention and the universalization of international law have been instrumental to an imperial expansion that subordinated non-European peoples to European powers and their interests. Underlying his grand new narrative is the contention that the history of the relationship between international law and colonial peoples cannot be properly analysed within the "traditional historiographical framework". Instead, this history "must recognize" the "underlying assumptions of its foundational texts". ${ }^{164}$ This line of reasoning is of course appealing to those TWAIL scholars familiar with the post-modern critic's work: "the further important issue is the question of whether it is possible to create an international law that is not imperial". ${ }^{165}$ In consequence, some are adopting this approach.

Bret Bowden, for example, has recently reiterated the idea of international law as an instrument of the "Western imperial project" in some major European journals specialized in international law. ${ }^{166}$ In any case, the scholars

16I) Anghie, A. "Reading International Legal Texts: On the Indians lately discovered and sixteenth-century international law", American Society of International Law Proceedings, April I-4 (I998): 375 .

162) Anghie, A. "Francisco de Vitoria and the Colonial Origins of International Law", 5 Social \& Legal Studies 3 (1996): 32I-336.

163) Anghie, A. Imperialism, Sovereignty and the Making of International Law, Cambridge University Press, 2005, p. 9.

164) Anghie, A. "Reading ... op. cit. p. 375.

165) Anghie, A. Imperialism, Sovereignty and the Making ... op. cit. p. 317.

166) See Bowden, B. "The Colonial Origins of International Law: European Expansion and the Classical Standard of Civilisation", I Journal of History of International Law 7 (2005): I-23. See also Bowden, B., 3 European Journal of International Law I7 (2006): 689-692. 
from the other side of the Atlantic are the ones who seem most eager to push the argument even further. For Leslye Obiora, for example, Anghie's thesis identifies the seminal works of Francisco de Vitoria as "a watershed that engendered juridical techniques and institutions manifestly appropriated as license to live by plunder". In her opinion, it copiously depicts "the chameleonic persistence of Vitorian epochs belied by rituals of innovation in the international legal framework" ${ }^{167}$

The traditional post-modern critique of international law (international law as a tool of imperialism/colonialism) is currently proposing an alternative history of international law. This approach basically sustains that international law was an instrument of colonial oppression invented by Vitoria and others at the time of the Encounter of the New and Old World, and essentially continues to be so to the present day. However, in order to defend that conclusion, some standards of historiographical analysis have been abandoned. In addition, in selecting Vitoria, this literature seems to have chosen the wrong author. ${ }^{168}$ The blackfriar was among the first scholars to question the secular and spiritual legal instruments of dominion employed by the great powers of his time: Emperors and Popes. In doing so, he developed the ideas of the res publica of the whole world (as an overarching world political community called to bring together all peoples) and the law of peoples (as a set of shared rules regulating that community). In sum, by stretching his political and legal imagination, Francisco de Vitoria sketched the big idea of One World under a common set of rules. It is not difficult to argue that these ideas help to progressively rationalize social interaction on a worldwide scale.

167) Obiora, L. "Book review", 40 Law and Society Review (2006): 729.

168) See Cavallar, G. "Vitoria, Grotius ... op. cit. I84. 
